\title{
Prevalence of comorbid psychiatric disorders among people with autism spectrum disorder: An umbrella review of systematic reviews and meta-analyses
}

\author{
Md Mahbub Hossain*, ${ }^{\mathrm{a}}$ Nusrat Khan, ${ }^{\mathrm{b}}$ Abida Sultana, ${ }^{\mathrm{c}}$ Ping Ma, \\ E. Lisako J. McKyer, ${ }^{\mathrm{a}}$ Helal Uddin Ahmed, ${ }^{\mathrm{d}}$ Neetu Purohit ${ }^{\mathrm{e}}$
}

\begin{abstract}
With ever-increasing prevalence of various mental disorders worldwide, a comprehensive evaluation of the prevalence of co-occurring psychiatric disorders among individuals with autism spectrum disorder (ASD) is needed to strengthen the knowledge base. This umbrella review aims to summarize the current evidence on the prevalence of comorbid psychiatric disorders among people with ASD. A systematic search of 12 major databases and additional sources was conducted. Any systematically conducted narrative, qualitative, or meta-analytic review reporting the prevalence of psychiatric disorders among people with ASD with no age or geographical restriction were included. From a total of 2755 records, 26 articles representing 14 systematic reviews and 12 meta-analyses met the criteria of this review. The synthesized findings reveal a high burden of comorbid psychiatric disorders among people with ASD, including anxiety disorders, depressive disorders, bipolar and mood disorders, schizophrenia spectrum, suicidal behavior disorders, attention-deficit/hyperactivity disorder, disruptive, impulse-control and conduct disorders amongst diverse age groups, with a majority in younger participants. Most studies were conducted in developed nations, with limited evidence from low and middle-income countries. These synthesized findings provide high-quality evidence for clinical and policy-level decision-making from a global overview of the status of comorbid psychiatric disorders among people with ASD.
\end{abstract}

Keywords: Neurodevelopmental Disorders; Autism Spectrum Disorders, Mental Disorders; Comorbidity; Multimorbidity; Epidemiology

\footnotetext{
a. Department of Health Promotion and Community Health Sciences, School of Public Health, Texas A\&M University, TX 77843, USA.

b. Department of Public Health and Primary Care, University of Cambridge, UK.

c. Gazi Medical College, Khulna 09000, Bangladesh.

d. National Institute of Mental Health (NIMH), Sher-E-Bangla Nagar, Dhaka, 1207 Bangladesh.

e. The IIHMR University, Jaipur, Rajasthan 302029, India.

* Corresponding author: Md Mahbub Hossain, Texas A\&M School of Public Health, College Station, TX 77843, USA.

Email: mhossain@tamu.edu
} 


\section{Introduction}

Autism spectrum disorder (ASD) is a neurodevelopmental disorder of early-onset characterized by social-communication difficulties and repetitive or stereotypical behaviors (Masi et al., 2017). Nearly $1 \%$ of global prevalence makes ASD one of the widely discussed neuropsychiatric problems that critically affect the lives of the affected individuals, caregivers, and communities (Lyall et al., 2017). The long-term health outcomes associated with ASD continue to impose a high burden of care, which necessitates a scientific evaluation of how different comorbid conditions affect people with ASD (Hoefman et al., 2014; Masi et al., 2017). Among diverse cooccurring health conditions, the issue of psychiatric comorbidity in ASD has become more relevant in recent years as the Diagnostic and Statistical Manual of Mental Disorders (DSM-5) no longer excludes additional diagnoses among individuals with ASD (Romero et al., 2016). This inclusion is consistent with past research that ASD can co-occur with other psychiatric disorders (Brereton et al., 2006; Yerys et al., 2011). It is estimated that nearly 70\% of people with ASD experience at least one comorbid psychiatric disorder, whereas nearly $40 \%$ individuals may have two or more psychiatric disorders (DeFilippis, 2018). Individuals with ASD are likely to experience a higher prevalence of common mental disorders compared to the typically developed individuals (DeFilippis, 2018; Romero et al., 2016). Moreover, children with ASD have been found to have a higher burden of psychiatric comorbidity than children with intellectual disability (Romero et al., 2016). Previous studies have shown that psychiatric comorbidity in ASD significantly increases the difficulties in adaptive responses and affects the daily activities, decreases the quality of living, and accentuates problems like restlessness, passivity, social isolation, aggressiveness, irritability, or self-injury (Fitzpatrick et al., 2016). These problems are difficult to identify and address, which they coexist with a complex condition like ASD. It is well documented that diagnosing ASD is a difficult task due to the unique clinical and subclinical manifestations among individuals (Huerta and Lord, 2012); therefore, diagnosing co-occurring psychiatric disorders in ASD may be challenging for the mental healthcare providers. In addition, contexts with fewer human resources for mental health are likely to have an under-recognized burden of psychiatric comorbidities among people with ASD (Tekola et al., 2016). These challenges should be acknowledged to improve the diagnostic capacities for ASD and comorbid psychiatric disorders for early diagnosis and management. In this discourse, it is essential to understand the epidemiological burden of psychiatric comorbidity in ASD, which may enable effective policymaking and capacity building across health systems to improve mental healthcare for people with ASD (Baxter et al., 2015).

To strengthen the knowledge base on how different psychiatric disorders are distributed in the ASD population, an extensive evaluation of the prevalence of mental disorders among individuals with ASD is needed. While observational studies conducted in different places evaluating one or more psychiatric disorders may provide a partial picture of the population-level psychiatric burden in ASD, such findings can be synthesized in evidence-based reviews minimizing the methodological issues in individual studies and providing a collective overview of the problems. Therefore, systematically conducted reviews of empirical studies offer highquality evidence for clinical and policy-level decision-making (Garg et al., 2008). Given that more than 11 systematic reviews are published in a day (Bastian et al., 2010), there is a growing 
interest in synthesizing knowledge from published reviews, which is known as umbrella review, or systematic review of the reviews (Aromataris et al., 2015). This umbrella review systematically evaluated the current evidence on the prevalence of comorbid psychiatric disorders among people with ASD from systematic reviews and meta-analyses to inform future research, policymaking, and practice.

\section{Materials and methods}

\subsection{Search strategy of the review}

In this umbrella review, we adopted the Preferred Reporting Items for Systematic Reviews and Meta-Analyses (PRISMA) guidelines (Liberati et al., 2009), and the Joanna Briggs Institute (JBI) methodology for umbrella reviews (Aromataris et al., 2015). We searched MEDLINE, Academic Search Ultimate, PsycINFO, CINAHL Complete, Health Policy Reference Center, ERIC, Health Source (Nursing/Academic Edition), Child Development \& Adolescent Studies, PsycARTICLES, EMBASE, PubMed, and the Cochrane Library using specific keywords (see Table 1). The titles, abstracts, subject headings, and general keywords were searched with no language restrictions. In addition, we searched the references of selected articles and citing articles from Google Scholar using the "cited by" function. All databases and additional sources were searched from their inception to November 10, 2019, and the entire search process was repeated on December 25, 2019, for the last time. All the retrieved citations were uploaded to Rayyan cloud-based systematic review management system for further assessment (Ouzzani et al., 2016). 
Table 1: Search strategy and keywords for this umbrella review

\begin{tabular}{|c|c|}
\hline $\begin{array}{l}\text { Search } \\
\text { query }\end{array}$ & $\begin{array}{l}\text { Keywords (searched within titles, abstracts, subject headings like MeSH, and } \\
\text { general keywords) }\end{array}$ \\
\hline 1 & $\begin{array}{l}\text { "prevalence" OR “incidence” OR “epidemiology" OR "frequency" OR “cases" } \\
\text { OR "rate" }\end{array}$ \\
\hline 2 & $\begin{array}{l}\text { "autism” OR “autism spectrum disorder" OR ASD OR “autistic" OR “autistic } \\
\text { disorder" OR “Asperger" OR "pervasive developmental” OR "PDD” OR "PDD- } \\
\text { NOS" }\end{array}$ \\
\hline 3 & 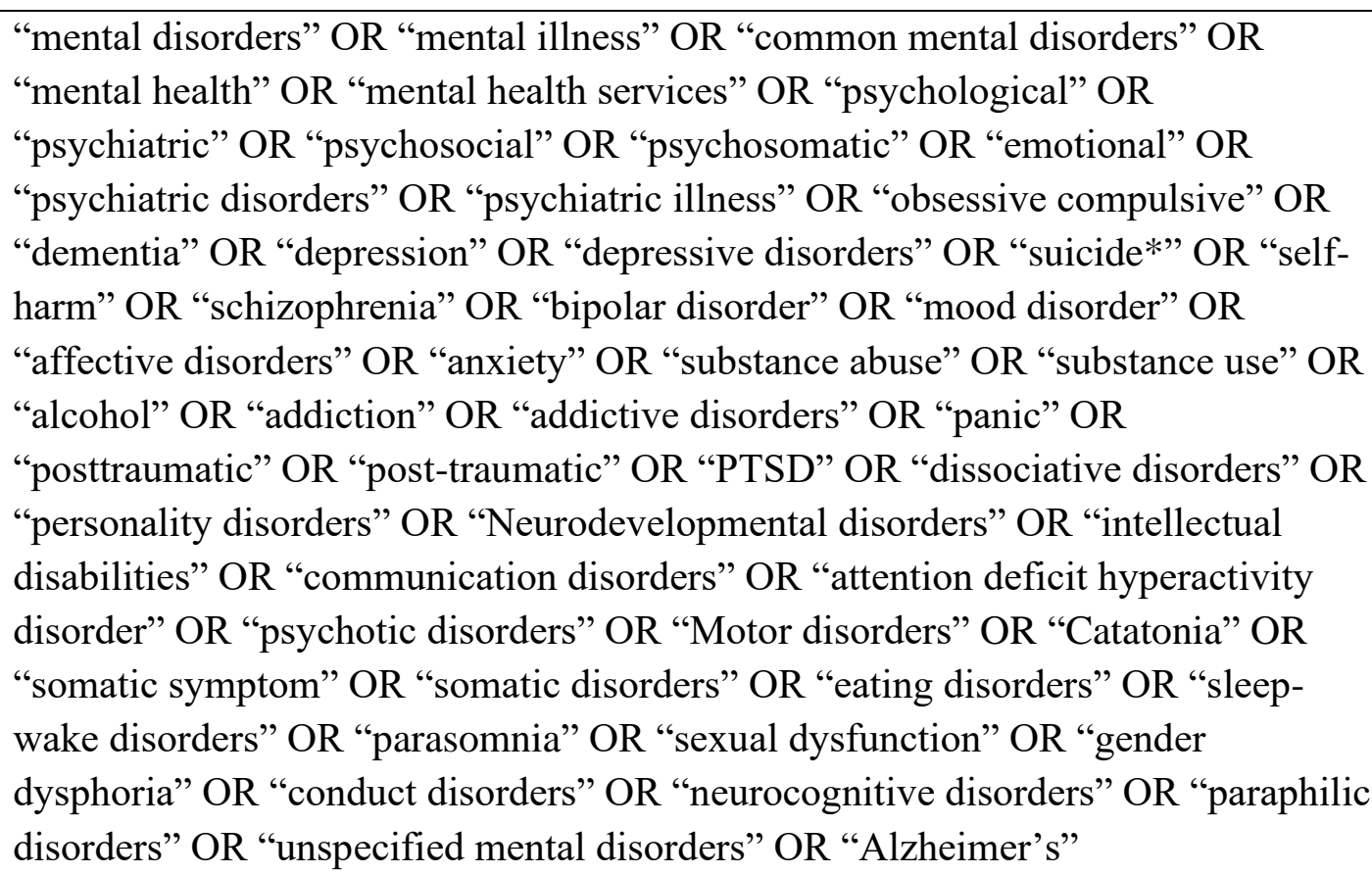 \\
\hline 4 & $\begin{array}{l}\text { "systematic review" OR “meta-analysis" OR "meta-regression” OR “pooled } \\
\text { effect" OR "pooled estimate" OR "pooled prevalence" }\end{array}$ \\
\hline $\begin{array}{l}\text { Final } \\
\text { search } \\
\text { query }\end{array}$ & 1 AND 2 AND 3 AND 4 \\
\hline
\end{tabular}

\subsection{Inclusion and exclusion criteria}

In this umbrella review, we included the systematically conducted narrative, qualitative, or metaanalytic reviews reporting the prevalence of psychiatric disorders among people with ASD. Also, any quantitative measures of disease burden, including odds ratio or relative risk expressing the epidemiological burden of psychiatric comorbidity in ASD, were also considered in the absence of a prevalence estimation. To further specify the psychiatric disorders as well as ASD, mental health conditions were included if they were defined within the classifications of psychiatric disorders in the International Classification of Diseases (ICD) tenth revision (World Health Organization (WHO), 2016), or the Diagnostic and Statistical Manual (DSM) fifth edition 
(American Psychiatric Association, 2013). Upon considering the historical evolution of the definitions and conceptual constructs for different psychiatric conditions, any disorder reported in the earlier versions of ICD or DSM were considered if they had an equivalent diagnosis classified under the current versions of these guidelines. Further, the reviews were recruited if they fulfilled all the inclusion criteria and excluded if they had conflicts with at least one of the exclusion criteria, as listed in Table 2 . Two authors independently evaluated all the retrieved citations. After the preliminary screening, potential conflicts on eligibility were addressed through discussion and consultation with a third author.

\section{Table 2: Eligibility criteria for this review}

\begin{tabular}{|l|l|}
\hline \multicolumn{1}{|c|}{ Inclusion criteria } & \multicolumn{1}{c|}{ Exclusion criteria } \\
\hline $\begin{array}{l}\text { 1. Articles published as systematically } \\
\text { conducted narrative, qualitative, or } \\
\text { quantitative (meta-analytic) literature reviews }\end{array}$ & $\begin{array}{l}\text { 1. Articles which were not systematically } \\
\text { conducted reviews (for example, narrative } \\
\text { and unstructured reviews, primary studies, } \\
\text { opinions, commentaries, letter, or editorials } \\
\text { were excluded) }\end{array}$ \\
\hline $\begin{array}{l}\text { 2. Articles reported prevalence (or other } \\
\text { quantitative measures like incidence, cases } \\
\text { with denominators, odds, or relative risks etc.) } \\
\text { of psychiatric disorders }\end{array}$ & $\begin{array}{l}\text { 2. Articles which did not report prevalence (or } \\
\text { other quantitative measures) of psychiatric } \\
\text { disorders only were excluded; articles } \\
\text { reporting psychiatric disorders within general } \\
\text { health outcomes were also excluded }\end{array}$ \\
\hline $\begin{array}{l}\text { 3. Articles reported primary studies where the } \\
\text { overall prevalence was provided for people } \\
\text { with ASD }\end{array}$ & $\begin{array}{l}\text { 3. Articles reported primary studies conducted } \\
\text { in general population or mixed population } \\
\text { groups without a focus on people with ASD } \\
\text { (for example, psychiatric disorders among } \\
\text { participants with diverse health conditions } \\
\text { including ASD was evaluated, and those were } \\
\text { excluded if they did not separately report the } \\
\text { prevalence among ASD population) }\end{array}$ \\
$\begin{array}{l}\text { 4. Articles not published in peer-reviewed } \\
\text { journals were excluded (for example, } \\
\text { dissertations, theses, policy papers, or } \\
\text { institutional reports were excluded) }\end{array}$ \\
\hline $\begin{array}{l}\text { 4. Articles published in peer-reviewed } \\
\text { journals }\end{array}$ & $\begin{array}{l}\text { 5. Articles were excluded if the full-texts } \\
\text { were not available in English }\end{array}$ \\
\hline $\begin{array}{l}\text { 5. Articles with full-texts available in the } \\
\text { English language }\end{array}$ &
\end{tabular}

\subsection{Data extraction and synthesis}

We developed a data extraction tool using the JBI data extraction tool for systematic reviews and research synthesis (Munn et al., 2014). Two authors independently extracted data on the following domains: the objectives and types of the review articles, year of publication, names of databases, the timeframe of searching the literature, sample size and characteristics, study location, recruitment strategy, and key findings on the prevalence of psychiatric disorders among individuals with ASD. Considering the high heterogeneity in terms of methodological approaches, instruments, and psychiatric outcomes, a narrative synthesis of the research findings 
was performed reporting the prevalence rates (percentage, proportion, odds ratio [OR], relative risk [RR], or other quantitative measures) with specific estimation or $95 \%$ confidence interval $[\mathrm{CI}]$ as reported in the respective reviews.

\subsection{Evaluation of the methodological quality}

In this umbrella review, we used the JBI critical appraisal checklist for systematic reviews and research synthesis checklist to assess the methodological quality of the included studies

(Aromataris et al., 2015). Two authors independently evaluated each of the included articles, which was finalized at the end of the primary evaluation through discussion with a third author. The checklist consists of ten items; each item can receive one point, and the overall quality score of a study can range from zero to ten. In this review, studies receiving zero to four, five to seven, and eight to ten were categorized as the low, medium, and high-quality studies, respectively. 

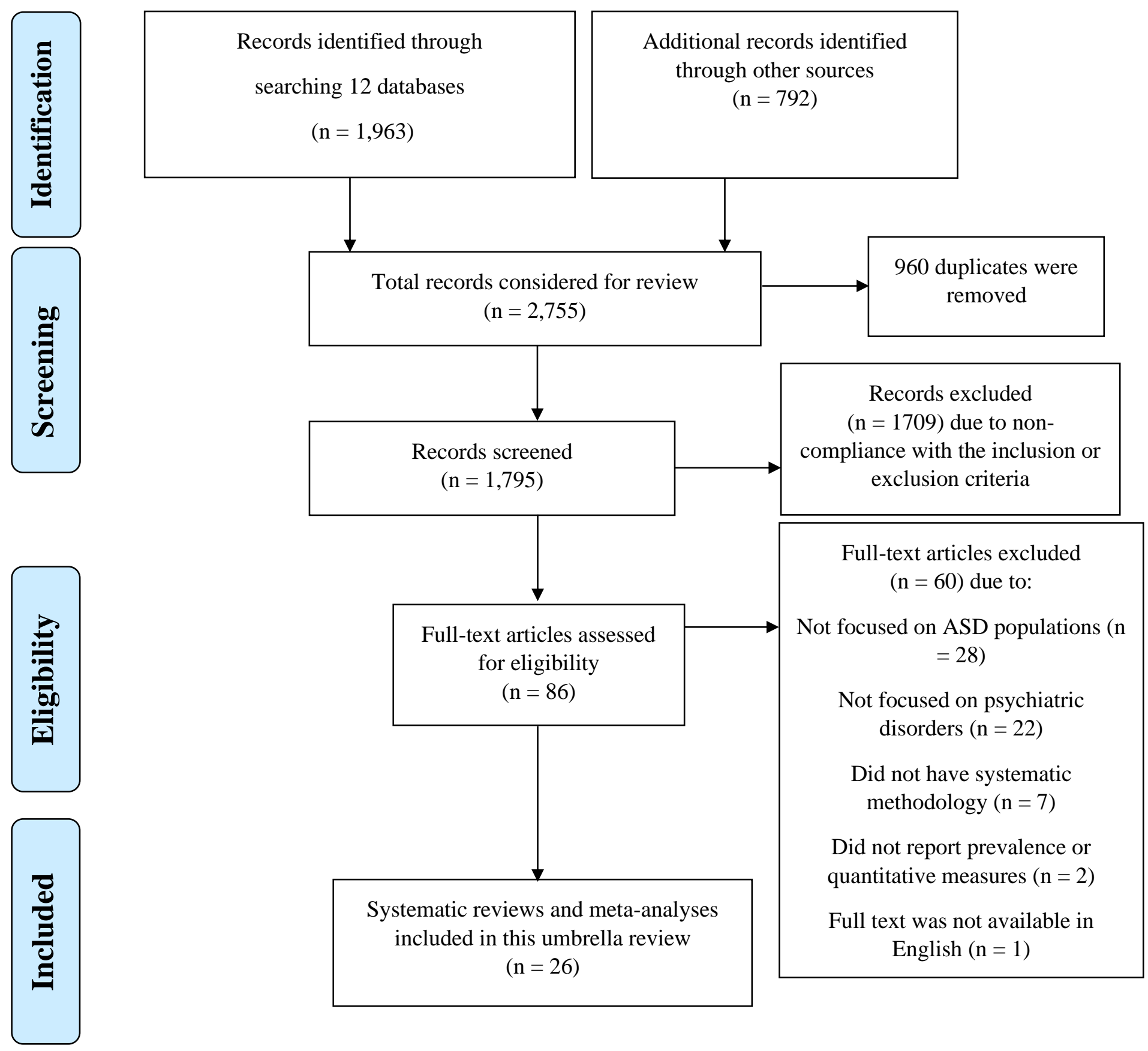

Figure 1: Flow diagram of the umbrella review 


\section{Results}

We found 1,963 citations from database searching and 792 citations from additional sources, totaling 2,755 citations (see Figure 1). After removing 960 duplicate citations, we screened the titles and abstracts of 1,795 and excluded 1,709 citations, which did not meet the criteria for this review. Further, we evaluated the full-texts of 86 articles and excluded 60 articles that did not meet all the criteria of this review. Finally, 26 articles meeting all the criteria were included in this umbrella review (see Table 3), including 14 systematic reviews (Arnevik and Helverschou, 2016; Hannon and Taylor, 2013; Hedley and Uljarević, 2018; Kalyva et al., 2016; Menezes et al., 2018; Nickel et al., 2019; Padgett et al., 2010; Richa et al., 2014; Segers and Rawana, 2014; Skokauskas and Gallagher, 2009; Stewart et al., 2006; Vannucchi et al., 2014; Wigham et al., 2017; Zahid and Upthegrove, 2017) and 12 meta-analyses (De Giorgi et al., 2019; Díaz-Román et al., 2018; Elrod and Hood, 2015; Hollocks et al., 2019; Hudson et al., 2019; Lai et al., 2019; Lugo-Marín et al., 2019; Lugo Marín et al., 2018; Morgan et al., 2020; van Steensel et al., 2011; van Steensel and Heeman, 2017; Zheng et al., 2018).

\subsection{Characteristics of the recruited reviews}

The earliest review included in this umbrella review was published in 2006 (Stewart et al., 2006). Most $(\mathrm{n}=17)$ reviews are published after 2015, whereas only nine reviews were published till 2015 (Elrod and Hood, 2015; Hannon and Taylor, 2013; Padgett et al., 2010; Richa et al., 2014; Segers and Rawana, 2014; Skokauskas and Gallagher, 2009; Stewart et al., 2006; van Steensel et al., 2011; Vannucchi et al., 2014). The number of the searched databases in the included reviews ranged from one to eight, with a median of four. Moreover, the number of primary studies in the included reviews ranged from four to 100 (Hannon and Taylor, 2013; Lai et al., 2019).

Among 26 reviews included in this review, 15 reviews reported the origin of the primary study populations. Most reviews included primary studies from the US, UK, Canada, Netherlands, Sweden, Italy, Norway, Germany, Australia, and other countries from North America, Europe, and Oceania whereas nine reviews included at least one country from Asia (Díaz-Román et al., 2018; Elrod and Hood, 2015; Hedley and Uljarević, 2018; Lai et al., 2019; Lugo-Marín et al., 2019; Lugo Marín et al., 2018; Segers and Rawana, 2014; Wigham et al., 2017; Zahid and Upthegrove, 2017). No primary studies were found from Africa, Central America, or Latin America.

The quality evaluation found fourteen reviews with high quality (De Giorgi et al., 2019; DíazRomán et al., 2018; Elrod and Hood, 2015; Hollocks et al., 2019; Hudson et al., 2019; Lai et al., 2019; Lugo-Marín et al., 2019; Lugo Marín et al., 2018; Menezes et al., 2018; Morgan et al., 2020; van Steensel et al., 2011; van Steensel and Heeman, 2017; Wigham et al., 2017; Zheng et al., 2018), twelve reviews with medium quality (Arnevik and Helverschou, 2016; Hannon and Taylor, 2013; Hedley and Uljarević, 2018; Kalyva et al., 2016; Nickel et al., 2019; Padgett et al., 2010; Richa et al., 2014; Segers and Rawana, 2014; Skokauskas and Gallagher, 2009; Stewart et al., 2006; Vannucchi et al., 2014; Zahid and Upthegrove, 2017), and no studies had low quality (see the Supplementary material). 
Table 3: Characteristics and the key findings of the included systematic reviews and meta-analyses

\begin{tabular}{|c|c|c|c|c|c|}
\hline $\begin{array}{l}\text { Author and } \\
\text { year of } \\
\text { publication }\end{array}$ & $\begin{array}{l}\text { Name(s) and } \\
\text { timeframe of } \\
\text { searching Databases }\end{array}$ & $\begin{array}{l}\text { Number of } \\
\text { primary } \\
\text { studies; } \\
\text { type of } \\
\text { review } \\
\text { (meta- } \\
\text { analysis or } \\
\text { systematic } \\
\text { review) } \\
\end{array}$ & $\begin{array}{l}\text { Sample sizes in } \\
\text { the included } \\
\text { primary } \\
\text { studies (total } \\
\text { or range as } \\
\text { reported in } \\
\text { respective } \\
\text { reviews) }\end{array}$ & $\begin{array}{l}\text { Characteristics of the study } \\
\text { populations with Autism } \\
\text { Spectrum Disorders or } \\
\text { equivalent conditions } \\
\text { (demographics, recruitment } \\
\text { strategy, and location) }\end{array}$ & $\begin{array}{l}\text { Prevalence rates (or other quantitative } \\
\text { measures of epidemiological burden as } \\
\text { specified), and related key findings }\end{array}$ \\
\hline $\begin{array}{l}\text { (Stewart et } \\
\text { al., 2006) }\end{array}$ & $\begin{array}{l}\text { MEDLINE, } \\
\text { PsycINFO, Web of } \\
\text { Science, and additional } \\
\text { sources; studies } \\
\text { published till } 2003\end{array}$ & $\begin{array}{l}27 \\
\text { Systematic } \\
\text { review }\end{array}$ & $\begin{array}{l}\text { Sample size } \\
\text { ranged from } 8 \\
\text { to } 85\end{array}$ & $\begin{array}{l}\text { Participants were children, } \\
\text { adolescents and adults with } \\
\text { Asperger syndrome, Pervasive } \\
\text { Developmental Disorder-Not } \\
\text { Otherwise Specified (PDD- } \\
\text { NOS) and other diagnoses of } \\
\text { ASD; mostly recruited from } \\
\text { clinical settings; locations of } \\
\text { the studies were not specified }\end{array}$ & $\begin{array}{l}\text { The prevalence of depression or depressive } \\
\text { symptoms ranged from } 4 \% \text { to } 18 \%\end{array}$ \\
\hline $\begin{array}{l}\text { (Skokauskas } \\
\text { and } \\
\text { Gallagher, } \\
\text { 2009) }\end{array}$ & $\begin{array}{l}\text { PubMed, PsycINFO, } \\
\text { Embase, Science } \\
\text { Direct, Ovid online, } \\
\text { and additional sources; } \\
\text { studies published till } \\
2008\end{array}$ & $\begin{array}{l}27 \\
\text { Systematic } \\
\text { review }\end{array}$ & $\begin{array}{l}\text { Sample size } \\
\text { ranged from } 10 \\
\text { to } 200\end{array}$ & $\begin{array}{l}\text { Both children and adults with } \\
\text { Asperger and other forms of } \\
\text { ASD were included; } \\
\text { recruitment strategy and } \\
\text { locations of the studies were } \\
\text { not specified }\end{array}$ & $\begin{array}{l}\text { The prevalence rates of schizophrenia (ranged } \\
\text { from } 0 \% \text { to } 50 \% \text { ), mood disorders (ranged from } \\
4.4 \% \text { to } 28.6 \% \text { ), and anxiety disorders (ranged } \\
\text { from } 1.47 \% \text { to } 84.1 \% \text { ) were reported across } \\
\text { study samples }\end{array}$ \\
\hline $\begin{array}{l}\text { (Padgett et } \\
\text { al., 2010) }\end{array}$ & $\begin{array}{l}\text { MEDLINE, } \\
\text { PsycINFO, and } \\
\text { additional sources; } \\
\text { from the inception of } \\
\text { the databases to } 2007\end{array}$ & $\begin{array}{l}19 ; \\
\text { Systematic } \\
\text { review }\end{array}$ & $\begin{array}{l}\text { Sample size } \\
\text { ranged from } 18 \\
\text { to } 322\end{array}$ & $\begin{array}{l}\text { Most samples had higher } \\
\text { proportion of child participants } \\
\text { with PDD and other ASD; } \\
\text { samples were recruited from } \\
\text { diverse settings including } \\
\text { health facilities, clinic } \\
\text { registries, autism } \\
\text { organizations, and community } \\
\text { settings; studies were } \\
\text { conducted in the US, Denmark, } \\
\text { and other non-specified } \\
\text { locations }\end{array}$ & $\begin{array}{l}\text { The rates of psychosis among individuals with } \\
\text { pervasive developmental disorders (PDD) varied } \\
\text { from } 0 \% \text { to } 53 \% \text { (median } 0 \% \text {, mean } 11 \% \text { ); the } \\
\text { incidence of co-morbid schizophrenia was up to } \\
7.8 \% \text { compared to } 1 \% \text { in general population }\end{array}$ \\
\hline
\end{tabular}




\begin{tabular}{|c|c|c|c|c|c|}
\hline $\begin{array}{l}\text { (van } \\
\text { Steensel et } \\
\text { al., 2011) }\end{array}$ & $\begin{array}{l}\text { PsycINFO, PubMed, } \\
\text { Web of Science, } \\
\text { ERIC; timeframe not } \\
\text { specified }\end{array}$ & $\begin{array}{l}\text { 31; Meta- } \\
\text { analysis }\end{array}$ & $\begin{array}{l}\text { The total } \\
\text { sample was } \\
2,121 \text { (ranged } \\
\text { from } 7 \text { to } 301 \text { ) }\end{array}$ & $\begin{array}{l}\text { Children and adolescent } \\
\text { participants with different ASD } \\
\text { subtypes were included; } \\
\text { recruitment site and study } \\
\text { locations were not specified }\end{array}$ & $\begin{array}{l}\text { The prevalence of at least one comorbid DSM- } \\
\text { IV anxiety disorder was } 39.6 \% \text { and } 34.8 \% \text { in } \\
\text { fixed and random effects models, respectively; in } \\
\text { random-effects analyses in subgroups, the } \\
\text { prevalence rates were } 17.4 \%, 16.6 \%, 29.8 \% \text {, } \\
15.4 \%, 9 \%, 1.8 \% \text {, and } 16.6 \% \text { for obsessive } \\
\text { compulsive disorders, social anxiety disorder, } \\
\text { specific phobia, generalized anxiety disorder, } \\
\text { separation anxiety disorder, panic disorder, and } \\
\text { agoraphobia. Specific anxiety disorders were } \\
\text { associated with different ASD subtype, age, IQ, } \\
\text { and assessment methods }\end{array}$ \\
\hline $\begin{array}{l}\text { (Hannon } \\
\text { and Taylor, } \\
\text { 2013) }\end{array}$ & $\begin{array}{l}\text { PsycINFO, } \\
\text { MEDLINE, Web of } \\
\text { Science and the } \\
\text { Cochrane Library; } \\
\text { studies published up to } \\
2012\end{array}$ & $\begin{array}{l}4 ; \\
\text { Systematic } \\
\text { review }\end{array}$ & $\begin{array}{l}\text { Sample size } \\
\text { ranged from } 12 \\
\text { to } 182\end{array}$ & $\begin{array}{l}\text { Three clinical and one } \\
\text { community sample were } \\
\text { recruited comprising of } \\
\text { children, adolescents, and } \\
\text { young adults with ASD; study } \\
\text { locations were not specified }\end{array}$ & $\begin{array}{l}\text { The lifetime prevalence of suicidal attempt was } \\
7-8.5 \% \text { among individuals with ASD and no } \\
\text { history of abuse; the rates increased up to } 31.6 \% \\
\text { and } 40 \% \text { for individuals who are abused } \\
\text { physically or sexually, respectively; suicidal } \\
\text { behavior was associated with the severity of } \\
\text { ASD symptoms ( } \mathrm{p}=.001 \text { ) }\end{array}$ \\
\hline $\begin{array}{l}\text { (Segers and } \\
\text { Rawana, } \\
\text { 2014) }\end{array}$ & $\begin{array}{l}\text { PsycINFO, Web of } \\
\text { Science, MEDLINE, } \\
\text { and additional sources; } \\
\text { searched till } 2013\end{array}$ & $\begin{array}{l}10 ; \\
\text { Systematic } \\
\text { review }\end{array}$ & $\begin{array}{l}\text { Sample size } \\
\text { ranged from } 5 \\
\text { to } 537\end{array}$ & $\begin{array}{l}\text { Most of the participants in the } \\
\text { included studies were male } \\
\text { with ASD; } 40 \% \text { studies had } \\
\text { adult participants, } 40 \% \text { had } \\
\text { child participants (3-10 years), } \\
50 \% \text { adolescent participants } \\
\text { (11-17 years), and 20\% } \\
\text { conducted research with } \\
\text { emerging adults; research } \\
\text { settings included hospitals } \\
\text { (40\%), community clinics } \\
(30 \%) \text {, universities (10\%), } \\
\text { mail-based questionnaires } \\
\text { (10\%), and web-based } \\
\text { interfaces (10\%); most studies } \\
\text { were from the US (n =4), } \\
\text { followed by European } \\
\text { countries (n = 3; United } \\
\text { Kingdom, Italy, Sweden), }\end{array}$ & $\begin{array}{l}\text { Suicidality was prevalent in } 10.9-50 \% \text { of the } \\
\text { ASD samples identified in the systematic review. } \\
\text { Further, several large-scale studies found that } \\
\text { individuals with ASD comprised } 7.3-15 \% \text { of } \\
\text { suicidal populations. Individuals with peer } \\
\text { victimization, behavioral problems, being Black } \\
\text { or Hispanic, being male, lower socioeconomic } \\
\text { status, and lower level of education had a higher } \\
\text { prevalence of suicidal behaviour disorder }\end{array}$ \\
\hline
\end{tabular}




\begin{tabular}{|c|c|c|c|c|c|}
\hline & & & & $\begin{array}{l}\text { Japan }(\mathrm{n}=2) \text {, and Turkey }(\mathrm{n}= \\
\text { 1). }\end{array}$ & \\
\hline $\begin{array}{l}\text { (Richa et al., } \\
\text { 2014) }\end{array}$ & $\begin{array}{l}\text { PubMed, PsycINFO, } \\
\text { Embase, and } \\
\text { MEDLINE; timeframe } \\
\text { was not specified }\end{array}$ & $\begin{array}{l}14 ; \\
\text { Systematic } \\
\text { review }\end{array}$ & $\begin{array}{l}\text { Sample size } \\
\text { ranged from } 10 \\
\text { to } 791\end{array}$ & $\begin{array}{l}\text { Children and adults with PDD } \\
\text { and other ASD were included; } \\
\text { recruitment was done in } \\
\text { diverse settings including } \\
\text { clinical and community } \\
\text { settings, advertisements, } \\
\text { referrals, and patient groups; } \\
\text { studies from Sweden and } \\
\text { Denmark were reported; } \\
\text { location was not specified for } \\
\text { most studies }\end{array}$ & $\begin{array}{l}\text { The prevalence of suicidal ideation ranged from } \\
10.9 \% \text { to } 50 \% \text {, and suicidal attempt ranged from } \\
7.2 \% \text { to } 15 \% \text {; the prevalence of psychiatric co- } \\
\text { morbidity among ASD samples was } 94 \% \text { for at } \\
\text { least one comorbid condition including anxiety } \\
(54 \%) \text {, disruptive behavior disorder ( } 48 \% \text { ), and } \\
\text { mood disorder (37\%) }\end{array}$ \\
\hline $\begin{array}{l}\text { (Vannucchi } \\
\text { et al., 2014) }\end{array}$ & $\begin{array}{l}\text { PubMed, Scopus, } \\
\text { PsycINFO; timeframe } \\
\text { not specified }\end{array}$ & $\begin{array}{l}7 ; \\
\text { Systematic } \\
\text { review }\end{array}$ & $\begin{array}{l}\text { Sample size } \\
\text { ranged from } 44 \\
\text { to } 4,343\end{array}$ & $\begin{array}{l}\text { Samples comprised of children, } \\
\text { adolescents, and adults with } \\
\text { Asperger syndrome; } \\
\text { participants were recruited } \\
\text { from academic, clinical, and } \\
\text { community settings; three } \\
\text { studies from Sweden, France, } \\
\text { and other developed countries } \\
\text { were reported }\end{array}$ & $\begin{array}{l}\text { The prevalence of bipolar disorder ranged from } \\
6 \% \text { to } 21.4 \% \text { among individuals with ASD }\end{array}$ \\
\hline $\begin{array}{l}\text { (Elrod and } \\
\text { Hood, 2015) }\end{array}$ & $\begin{array}{l}\text { PubMed, Scopus, } \\
\text { Google Scholar, and } \\
\text { additional sources; } \\
\text { studies published since } \\
1994\end{array}$ & $\begin{array}{l}\text { 10; Meta- } \\
\text { analysis }\end{array}$ & $\begin{array}{l}\text { The total } \\
\text { sample was } 564 \\
\text { ( } 343 \text { children } \\
\text { with ASD, and } \\
221 \\
\text { traditionally } \\
\text { developed } \\
\text { children) }\end{array}$ & $\begin{array}{l}\text { Participants aged from } 2 \text { years } \\
\text { to } 19 \text { years with ASD; } \\
\text { recruited from clinical settings } \\
\text { and registries; most studies } \\
\text { were from the US }(n=5) \text {, } \\
\text { followed by Italy }(n=4) \text {, and } \\
\text { one study each from Israel and } \\
\text { Sweden }\end{array}$ & $\begin{array}{l}\text { Total sleep time (TST) for children with ASD } \\
\text { was on average } 32.8 \text { minutes less per day ( } 95 \% \\
\text { confidence interval [CI]: 16.6-49.0), the average } \\
\text { sleep latency (SL) was 10.9 minutes longer (95\% } \\
\text { CI: 6.7-15.0), average sleep efficiency (SE) was } \\
1.9 \% \text { less (95\% CI: 0.7-3.1) than their } \\
\text { traditionally developed (TD) peers. Concurrent } \\
\text { intellectual disability was reported as a } \\
\text { moderator of TST; children with ASD and } \\
\text { intellectual disability (ID) had a significantly } \\
\text { decreased TST as compared with TD peers. } \\
\text { Also, medication use, method of data collection, } \\
\text { and age moderated the prevalence of sleep } \\
\text { problems among children with ASD }\end{array}$ \\
\hline $\begin{array}{l}\text { (Kalyva et } \\
\text { al., 2016) }\end{array}$ & $\begin{array}{l}\text { PsycINFO, } \\
\text { PsychARTICLES, } \\
\text { ERIC, Psychology \& }\end{array}$ & $\begin{array}{l}20 \\
\text { Systematic } \\
\text { review }\end{array}$ & $\begin{array}{l}\text { Sample size } \\
\text { ranged from } 3\end{array}$ & $\begin{array}{l}\text { Both adults and children with } \\
\text { ASD were recruited across } \\
\text { studies from diverse settings }\end{array}$ & $\begin{array}{l}\text { The prevalence of Tourette syndrome or tic } \\
\text { disorders ranged from } 2.6 \% \text { to } 36 \% \text { across } \\
\text { different samples. The co-occurrence of those }\end{array}$ \\
\hline
\end{tabular}




\begin{tabular}{|c|c|c|c|c|c|}
\hline & $\begin{array}{l}\text { Behavioral Sciences, } \\
\text { Academic Search } \\
\text { Primer, and } \\
\text { MEDLINE; studies } \\
\text { published till } 2015\end{array}$ & & $\begin{array}{l}\text { to } 447 \text { in ASD } \\
\text { populations }\end{array}$ & $\begin{array}{l}\text { including clinics and schools; } \\
\text { study locations were not } \\
\text { specified }\end{array}$ & $\begin{array}{l}\text { disorders and ASD ranged from } 4 \% \text { to } 12 \% \\
\text { among the study populations }\end{array}$ \\
\hline $\begin{array}{l}\text { (Arnevik } \\
\text { and } \\
\text { Helverschou } \\
\text {, 2016) }\end{array}$ & $\begin{array}{l}\text { PubMed, PsycINFO, } \\
\text { MEDLINE, and } \\
\text { additional sources; } \\
\text { studies published till } \\
\text { January } 2016\end{array}$ & $\begin{array}{l}18 ; \\
\text { Systematic } \\
\text { review }\end{array}$ & $\begin{array}{l}\text { Sample size } \\
\text { ranged from } 14 \\
\text { to } 414\end{array}$ & $\begin{array}{l}\text { Participants with ASD were } \\
\text { recruited; most studies had a } \\
\text { high male-to-female ratio; } \\
\text { participants aged above } 12 \\
\text { were included from clinical } \\
\text { settings and registries; study } \\
\text { locations were not reported }\end{array}$ & $\begin{array}{l}\text { The prevalence of substance use disorder ranged } \\
\text { from } 0.7 \% \text { to } 36 \% \text { among individuals with ASD }\end{array}$ \\
\hline $\begin{array}{l}\text { (van } \\
\text { Steensel and } \\
\text { Heeman, } \\
\text { 2017) }\end{array}$ & $\begin{array}{l}\text { PsycINFO, PubMed, } \\
\text { Web of Science and } \\
\text { ERIC; studies } \\
\text { published till } 2016\end{array}$ & $\begin{array}{l}83 \text {; Meta- } \\
\text { analysis }\end{array}$ & $\begin{array}{l}\text { Sample size } \\
\text { ranged from } 7 \\
\text { to } 381\end{array}$ & $\begin{array}{l}\text { Children with ASD and } \\
\text { typically developed children } \\
\text { were recruited across studies; } \\
\text { recruitment strategy was not } \\
\text { specified; however, clinical } \\
\text { samples were predominantly } \\
\text { reported; study locations were } \\
\text { not reported }\end{array}$ & $\begin{array}{l}\text { Children with ASD had higher anxiety levels } \\
\text { (effect sizes ranged between } 0.11 \text { to } 0.91 \text { in } \\
\text { fixed-effect models and } 0.12 \text { to } 1.21 \text { in random- } \\
\text { effects models) compared to typically developed } \\
\text { or clinically referred youth without ASD; in } \\
\text { contrast, children with ASD had lower anxiety } \\
\text { levels (-0.12 and - } 0.45 \text { in fixed and random- } \\
\text { effects models, respectively) compared to youth } \\
\text { with internalizing problems }\end{array}$ \\
\hline $\begin{array}{l}\text { (Wigham et } \\
\text { al., 2017) }\end{array}$ & $\begin{array}{l}\text { MEDLINE, Embase, } \\
\text { CINAHL, ERIC, and } \\
\text { PsycINFO; 1992-2015 }\end{array}$ & $\begin{array}{l}19 ; \\
\text { Systematic } \\
\text { review }\end{array}$ & $\begin{array}{l}\text { Sample size } \\
\text { ranged from } 10 \\
\text { to } 474\end{array}$ & $\begin{array}{l}\text { Children and adults with high } \\
\text { functioning ASD were } \\
\text { recruited clinical and } \\
\text { educational settings, registries, } \\
\text { autism support groups and web } \\
\text { sources; most of the studies } \\
\text { were conducted in the US }(\mathrm{n}= \\
\text { 6), followed by the UK }(\mathrm{n}=4), \\
\text { Australia }(\mathrm{n}=2), \text { Sweden }(\mathrm{n}= \\
\text { 2), and one study each from } \\
\text { Turkey, Finland, and the } \\
\text { Netherlands; two studies } \\
\text { recruited participants from } \\
\text { more than one country }\end{array}$ & $\begin{array}{l}\text { The self-reported prevalence of depressive } \\
\text { disorder ranged from } 4 \% \text { to } 47.1 \% \text {. Moreover, } \\
\text { the informant reported rates of depressive } \\
\text { disorder ranged from } 2.5 \% \text { to } 29 \% \text {. The rates } \\
\text { were different based on psychometric measures; } \\
\text { for example, Autism Co-morbidity Interview } \\
\text { found } 15.8 \% \text { of participants had depressive } \\
\text { disorder whereas Child Symptom Inventory } \\
\text { reported rates ranged between } 0 \% \text { to } 6.2 \%\end{array}$ \\
\hline $\begin{array}{l}\text { (Zahid and } \\
\text { Upthegrove, } \\
\text { 2017) }\end{array}$ & $\begin{array}{l}\text { PsycINFO, } \\
\text { MEDLINE, Embase, } \\
\text { Web of Science and } \\
\text { additional sources; }\end{array}$ & $\begin{array}{l}12 ; \\
\text { Systematic } \\
\text { review }\end{array}$ & $\begin{array}{l}\text { Samples with } \\
\text { ASD ranged } \\
\text { from } 10 \text { to } 791\end{array}$ & $\begin{array}{l}\text { Children, adolescents, and } \\
\text { adults with ASD from diverse } \\
\text { settings were recruited; most } \\
\text { studies were from the US }(\mathrm{n}= \\
\text { 5), followed by Japan }(\mathrm{n}=3),\end{array}$ & $\begin{array}{l}\text { The prevalence of suicidal ideation or attempts } \\
\text { ranged between } 3.8 \% \text { to } 66 \% \text {. Studies have also } \\
\text { reported a high prevalence of psychiatric co- } \\
\text { morbidity among ASD samples including } \\
\text { anxiety }(54 \%) \text {, schizophrenia }(67 \%) \text {, disruptive }\end{array}$ \\
\hline
\end{tabular}




\begin{tabular}{|c|c|c|c|c|c|}
\hline & $\begin{array}{l}\text { studies published till } \\
2014\end{array}$ & & & $\begin{array}{l}\text { and one study each from the } \\
\text { UK, Canada, Turkey, and Italy }\end{array}$ & $\begin{array}{l}\text { behavior disorder (48\%), and mood disorder } \\
(37 \%)\end{array}$ \\
\hline $\begin{array}{l}\text { (Hollocks et } \\
\text { al., 2019) }\end{array}$ & $\begin{array}{l}\text { PsycINFO, PubMed, } \\
\text { and Web of Science; } \\
2000-2017\end{array}$ & $\begin{array}{l}35 \text {; Meta- } \\
\text { analysis }\end{array}$ & $\begin{array}{l}\text { Sample sizes } \\
\text { were } 26,070 \text { for } \\
\text { studies } \\
\text { reporting } \\
\text { anxiety and } \\
26,117 \text { for } \\
\text { studies } \\
\text { reporting } \\
\text { depression } \\
\text { (range } 13 \text { to } \\
22,253 \text { ) }\end{array}$ & $\begin{array}{l}\text { All were adult participants with } \\
\text { ASD; majority of male and } \\
\text { most samples were collected } \\
\text { from clinical settings followed } \\
\text { by communities and referrals } \\
\text { or contacts; Most studies ( }= \\
\text { 10) were from the US, } \\
\text { followed by the UK }(\mathrm{n}=6) \text {, } \\
\text { Sweden }(\mathrm{n}=5), \text { Netherlands ( } \\
=3 \text { ), and one study each from } \\
\text { Germany and Norway; one } \\
\text { study recruited participants } \\
\text { from both France and Sweden }\end{array}$ & 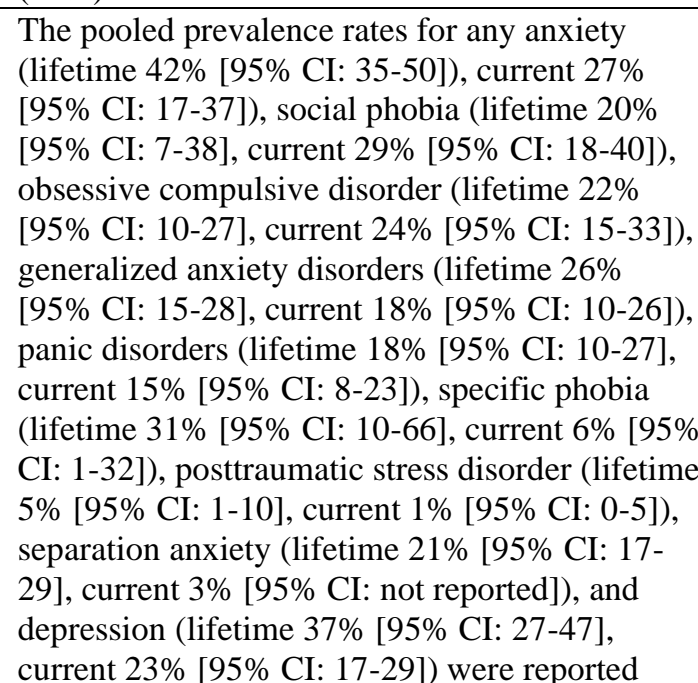 \\
\hline $\begin{array}{l}\text { (Hudson et } \\
\text { al., 2019) }\end{array}$ & $\begin{array}{l}\text { PubMed, Web of } \\
\text { Science, PsycINFO, } \\
\text { CINAHL, and } \\
\text { ProQuest Dissertations } \\
\text { and Theses; studies } \\
\text { published till } 2016\end{array}$ & $\begin{array}{l}\text { 66; Meta- } \\
\text { analysis }\end{array}$ & $\begin{array}{l}\text { Sample size } \\
\text { ranged from } 4 \\
\text { to } 22\end{array}$ & $\begin{array}{l}\text { Both children and adult } \\
\text { participants with ASD were } \\
\text { recruited from community and } \\
\text { outpatient settings; study } \\
\text { locations were not specified }\end{array}$ & $\begin{array}{l}\text { The pooled prevalence of lifetime and current } \\
\text { depressive disorders were 14.4\% (95\% CI 10.3- } \\
\text { 19.8) and } 12.3 \% \text { (95\% CI 9.7-15.5), } \\
\text { respectively; the prevalence rates were higher } \\
\text { among studies with standardized interview } \\
\text { methods assessing depressive disorders (lifetime } \\
=28.5 \%, 95 \% \text { CI 20.1-38.8; current = } 15.3 \% \text {, } \\
95 \% \text { CI 11.0-20.9), self-reported depressive } \\
\text { symptoms (lifetime = 48.6\%, 95\% CI 33.3-64.2; } \\
\text { current = 25.9\%, 95\% CI 17.0-37.3), studies } \\
\text { with participants with higher intelligence; also, } \\
\text { the prevalence was higher in samples with older } \\
\text { and White participants }\end{array}$ \\
\hline $\begin{array}{l}\text { (Lugo } \\
\text { Marín et al., } \\
2018)\end{array}$ & $\begin{array}{l}\text { PsycINFO, } \\
\text { MEDLINE, CINAHL, } \\
\text { Embase, and } \\
\text { additional sources; } \\
\text { studies published till } \\
2016\end{array}$ & $\begin{array}{l}\text { 10; Meta- } \\
\text { analysis }\end{array}$ & $\begin{array}{l}\text { Sample size } \\
\text { ranged from } 15 \\
\text { to } 129\end{array}$ & $\begin{array}{l}\text { Adult participants with ASD } \\
\text { with average IQ were } \\
\text { recruited; recruitment sites } \\
\text { were not specified; most } \\
\text { studies }(\mathrm{n}=6) \text { were from } \\
\text { Sweden, followed by the US (n } \\
=2 \text { ), and one study each from }\end{array}$ & $\begin{array}{l}\text { The pooled prevalence of schizophrenia } \\
\text { spectrum disorders was } 6.4 \% \text { (95\% CI: } 4-10.1) \\
\text { among adults with ASD }\end{array}$ \\
\hline
\end{tabular}




\begin{tabular}{|c|c|c|c|c|c|}
\hline & & & & $\begin{array}{l}\text { Italy, Netherlands, Germany, } \\
\text { and Canada }\end{array}$ & \\
\hline $\begin{array}{l}\text { (Menezes et } \\
\text { al., 2018) }\end{array}$ & $\begin{array}{l}\text { MEDLINE and } \\
\text { PsycINFO; 2012-2016 }\end{array}$ & $\begin{array}{l}43 ; \\
\text { Systematic } \\
\text { review }\end{array}$ & $\begin{array}{l}\text { Sample size } \\
\text { ranged from } 10 \\
\text { to } 791 \text { (except a } \\
\text { case study) }\end{array}$ & $\begin{array}{l}\text { Study participants were } \\
\text { children and adolescents with } \\
\text { ASD; recruited from both } \\
\text { community and clinical } \\
\text { samples; study locations were } \\
\text { not specified }\end{array}$ & $\begin{array}{l}\text { The prevalence of depression ranged from } 7 \% \text { to } \\
47.1 \% \text { across samples of individuals with ASD }\end{array}$ \\
\hline $\begin{array}{l}\text { (Díaz- } \\
\text { Román et } \\
\text { al., 2018) }\end{array}$ & $\begin{array}{l}\text { PubMed (MEDLINE), } \\
\text { PsycINFO, Embase+ } \\
\text { Embase classic, Ovid } \\
\text { MEDLINE, Web of } \\
\text { Science, biological } \\
\text { abstracts, biosis, food } \\
\text { science and technology } \\
\text { abstracts; studies } \\
\text { published till } 2018\end{array}$ & $\begin{array}{l}48 \text {; Meta- } \\
\text { analysis }\end{array}$ & $\begin{array}{l}\text { Sample size } \\
\text { ranged from } 75 \\
\text { to } 5430\end{array}$ & $\begin{array}{l}\text { Children and adolescents with } \\
\text { ASD were included as study } \\
\text { participants; recruitment } \\
\text { strategy was not specified; } \\
\text { most studies were from the US } \\
(\mathrm{n}=9), \text { Australia }(\mathrm{n}=7), \\
\text { China }(\mathrm{n}=5) \text {, Italy }(\mathrm{n}=5) \text {. } \\
\text { Japan }(\mathrm{n}=3) \text {, two studies from } \\
\text { Turkey and Israel, one study } \\
\text { each from India, Oman, } \\
\text { Sweden, Russia, Iran, } \\
\text { Netherlands, Finland, France, } \\
\text { and Korea }\end{array}$ & 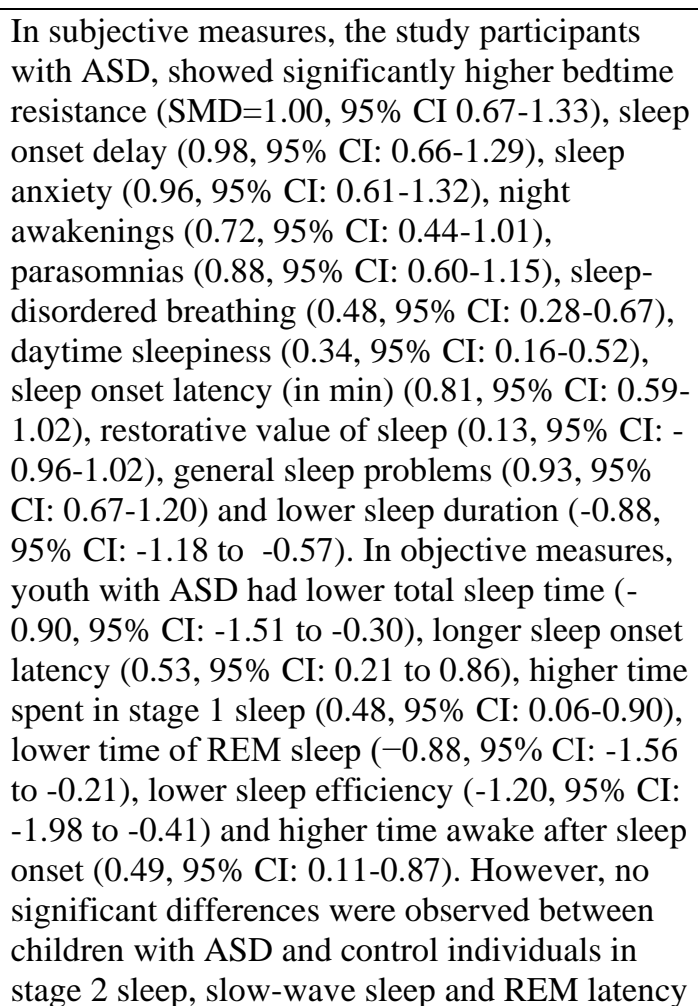 \\
\hline $\begin{array}{l}\text { (Hedley and } \\
\text { Uljarević, } \\
\text { 2018) }\end{array}$ & $\begin{array}{l}\text { PubMed, PsycINFO, } \\
\text { Web of Science and } \\
\text { additional sources; } \\
2012-17\end{array}$ & $\begin{array}{l}13 ; \\
\text { Systematic } \\
\text { review }\end{array}$ & $\begin{array}{l}\text { The total } \\
\text { sample size was } \\
30,663 \text { (ranging } \\
\text { from } 37 \text { to } \\
27,122 \text { ) }\end{array}$ & $\begin{array}{l}\text { Children and adults with ASD } \\
\text { were recruited from general } \\
\text { population and clinical } \\
\text { samples; Most studies were } \\
\text { from the US ( } \mathrm{n}=5 \text { ), Japan ( } \mathrm{n} \\
=3 \text { ), and one each from }\end{array}$ & $\begin{array}{l}\text { The prevalence of suicide ideation ranged from } \\
11 \% \text { to } 66 \% \text { and suicidal attempts from } 1 \% \text { to } \\
35 \% \text {; mortality due to suicide was } 0.31 \% \text { among } \\
\text { people with ASD compared to } 0.04 \% \text { among } \\
\text { traditionally developed individuals; the } \\
\text { prevalence of comorbid attention-deficit }\end{array}$ \\
\hline
\end{tabular}




\begin{tabular}{|c|c|c|c|c|c|}
\hline & & & & $\begin{array}{l}\text { Australia, Canada, Sweden, } \\
\text { Turkey, and the UK }\end{array}$ & $\begin{array}{l}\text { hyperactivity syndrome was reported as high as } \\
65 \% \text { among study samples }\end{array}$ \\
\hline $\begin{array}{l}\text { (Zheng et } \\
\text { al., 2018) }\end{array}$ & $\begin{array}{l}\text { PubMed, Embase, } \\
\text { Cochrane Library, and } \\
\text { additional sources; } \\
\text { studies published till } \\
2017\end{array}$ & $\begin{array}{l}\text { 17; Meta- } \\
\text { analysis }\end{array}$ & $\begin{array}{l}\text { Sample size } \\
\text { ranged from } 12 \\
\text { to } 9,062 \text { for } \\
\text { people with } \\
\text { ASD and } 12 \text { to } \\
1,842,575 \\
\text { among controls }\end{array}$ & $\begin{array}{l}\text { Participants with ASD of all } \\
\text { age group were included; the } \\
\text { recruitment strategy was not } \\
\text { specified; studies were } \\
\text { conducted in Denmark }(n=4), \\
\text { the US }(n=4), \text { Sweden }(n=3), \\
\text { and once study each in } \\
\text { Norway, Canada, Australia, } \\
\text { Finland, and the Netherlands }\end{array}$ & $\begin{array}{l}\text { The pooled prevalence of schizophrenia was } \\
\text { significantly higher among individuals with ASD } \\
\text { compared to the controls (OR }=3.55,95 \% \text { CI: } \\
2.08-6.05, \mathrm{P}<.001) \text {; also, the pooled prevalence } \\
\text { of ASD in individuals with schizophrenia } \\
\text { ranged from } 3.4 \text { to } 52 \% \text {; ASD participants in the } \\
\text { case-control studies had higher odds ( } 8.2,95 \% \\
\text { CI: } 3.25-20.66) \text { compare to cross-sectional } \\
\text { studies ( } 2.47,95 \% \text { CI: } 1.31-4.66) \text {; samples from } \\
\text { European countries had higher odds }(4.21,95 \% \\
\text { CI: } 1.8-9.85) \text { compared to the US samples (2.61, } \\
\text { 95\% CI: } 1.07-6.39)\end{array}$ \\
\hline $\begin{array}{l}\text { (De Giorgi } \\
\text { et al., 2019) }\end{array}$ & $\begin{array}{l}\text { PubMed/MEDLINE, } \\
\text { Web of Science, } \\
\text { CINAHL; studies } \\
\text { published till } 2019\end{array}$ & $\begin{array}{l}\text { 14; Meta- } \\
\text { analysis }\end{array}$ & $\begin{array}{l}\text { The total } \\
\text { sample size was } \\
1,708 \text { (ranged } \\
\text { from } 26 \text { to } 414 \text { ) }\end{array}$ & $\begin{array}{l}\text { Samples comprised of both } \\
\text { children and adults with ASD; } \\
\text { recruited from mostly } \\
\text { outpatient settings ( } 12 \text { out of } \\
14 \text { studies); studies were } \\
\text { conducted in Sweden }(\mathrm{n}=3), \\
\text { Denmark }(\mathrm{n}=3) \text {. The US }(\mathrm{n}= \\
\text { 2), and one study each from the } \\
\text { UK, Italy, France, Canada, } \\
\text { Norway; one study had } \\
\text { samples from both Sweden and } \\
\text { France }\end{array}$ & $\begin{array}{l}\text { The pooled prevalence of non-affective } \\
\text { psychoses or schizophrenia spectrum disorder } \\
\text { was } 9.5 \%(95 \% \text { CI }=2.6 \text { to } 16.0 \text { ) among } \\
\text { participants with ASD; the subgroup analyses } \\
\text { found higher prevalence ( } 20.6 \% \text { compared to } \\
9.1 \% \text { ) for inpatient studies compared to } \\
\text { outpatient studies, whereas participants older } \\
\text { than } 18 \text { years had higher prevalence ( } 10.1 \% \\
\text { compared to } 8.47 \% \text { ) compared to younger } \\
\text { participants; studies with lesser than } 100 \text { samples } \\
(19.6 \% \text { compared to } 6.36 \% \text { in samples above } \\
100) \text { and recent diagnostic methods like DSM-III } \\
\text { or later (11.7\%) and ICD } 10 \text { (12.5\%) had higher } \\
\text { prevalence compared to earlier versions of } \\
\text { diagnostic measures }\end{array}$ \\
\hline $\begin{array}{l}\text { (Lai et al., } \\
\text { 2019) }\end{array}$ & $\begin{array}{l}\text { MEDLINE, Embase, } \\
\text { PsycINFO, Scopus, } \\
\text { Web of Science, and } \\
\text { additional sources; } \\
\text { 1993-2019 }\end{array}$ & $\begin{array}{l}\text { 100; Meta- } \\
\text { analysis }\end{array}$ & $\begin{array}{l}\text { Sample size } \\
\text { ranged from } 23 \\
\text { to } 48,762 \text { across } \\
\text { studies and } \\
53,243 \text { to } \\
210,249 \text { in } \\
\text { pooled analyses }\end{array}$ & $\begin{array}{l}\text { Both children and adult } \\
\text { participants with ASD were } \\
\text { recruited from population- } \\
\text { based samples, registries, and } \\
\text { clinical settings; studies were } \\
\text { conducted in North America (n } \\
=36) \text {, Europe }(\mathrm{n}=38), \text { Middle } \\
\text { East }(\mathrm{n}=6) \text {, Australia }(\mathrm{n}=3), \\
\text { and Asia }(\mathrm{n}=4)\end{array}$ & $\begin{array}{l}\text { The pooled prevalence estimates was } 28 \% \text { (95\% } \\
\text { CI: 25-32) for attention-deficit hyperactivity } \\
\text { disorder; 20\% (95\% CI: 17-23) for anxiety } \\
\text { disorders; } 13 \% \text { ( } 95 \% \text { CI: 9-17) for sleep-wake } \\
\text { disorders; } 12 \% \text { ( } 95 \% \text { CI:10-15) for disruptive, } \\
\text { impulse-control, and conduct disorders; } 11 \% \\
\text { (95\% CI: 9-13) for depressive disorders; } 9 \% \\
\text { (95\% CI: 7-10) for obsessive-compulsive } \\
\text { disorder; 5\% (95\% CI: 3-6) for bipolar } \\
\text { disorders; and 4\% (95\% CI: 3-5) for } \\
\text { schizophrenia spectrum disorders }\end{array}$ \\
\hline
\end{tabular}




\begin{tabular}{|c|c|c|c|c|c|}
\hline $\begin{array}{l}\text { (Lugo- } \\
\text { Marín et al., } \\
\text { 2019) }\end{array}$ & $\begin{array}{l}\text { PsycINFO, PubMed, } \\
\text { CINAHL, Web of } \\
\text { Science, and additional } \\
\text { sources; 2000-2016 }\end{array}$ & $\begin{array}{l}47 \text {; Meta- } \\
\text { analysis }\end{array}$ & $\begin{array}{l}\text { The total } \\
\text { sample size was } \\
26,679\end{array}$ & $\begin{array}{l}\text { All participants were adults } \\
\text { with ASD; mostly }(74.35 \%) \\
\text { male; most of the studies } \\
(87 \%) \text { were conducted in } \\
\text { clinical settings; studies were } \\
\text { conducted in Sweden }(\mathrm{n}=13), \\
\text { UK }(\mathrm{n}=8), \text { USA }(\mathrm{n}=6), \\
\text { Netherlands }(\mathrm{n}=4) \text {, Denmark } \\
(\mathrm{n}=3) \text {, two studies each from } \\
\text { Japan and Finland, one study } \\
\text { each from Taiwan, Canada, } \\
\text { Scotland, Australia, and Italy }\end{array}$ & $\begin{array}{l}\text { The pooled prevalence rates of substance use } \\
\text { disorder }(8.3 \%, 95 \% \text { CI: } 4.1-16.1) \text {, } \\
\text { schizophrenia spectrum disorders (11.8\%, 95\% } \\
\text { CI: 7.7-17.6), mood disorder (18.8\%, 95\% CI: } \\
\text { 10.6-31.1), anxiety disorders (17.8\%, 95\% CI: } \\
\text { 12.3-25.2), eating disorders (3.6\%, 95\% CI: } 2.1- \\
\text { 6.1), personality disorders (12.6\%, 95\% CI: 4.8- } \\
\text { 29.3), attention deficit and hyperactivity disorder } \\
\text { (25.7\%, 95\% CI: } 18.6-34.3) \text { and presence of any } \\
\text { psychiatric disorder (54.8\%, 95\% CI: 46.6-62.7) } \\
\text { were reported }\end{array}$ \\
\hline $\begin{array}{l}\text { (Nickel et } \\
\text { al., 2019) }\end{array}$ & $\begin{array}{l}\text { Ovid MEDLINE; } \\
\text { studies published till } \\
\text { July, } 2019\end{array}$ & $\begin{array}{l}17 ; \\
\text { Systematic } \\
\text { review }\end{array}$ & $\begin{array}{l}\text { Sample size } \\
\text { ranged from } 10 \\
\text { to } 12,606\end{array}$ & $\begin{array}{l}\text { Both children and adults with } \\
\text { ASD were included; the } \\
\text { recruitment strategy and study } \\
\text { locations were not specified }\end{array}$ & $\begin{array}{l}\text { Three studies reported a higher risk of } \\
\text { developing eating disorders among individuals } \\
\text { with ASD; } 7.9 \% \text { had a current or previous eating } \\
\text { disorder (ED) including anorexia nervosa (AN) } \\
6.7 \% \text {, bulimia nervosa (BN) } 2.7 \% \text { and binge } \\
\text { eating disorder (BED) } 1.4 \% \text { ) }\end{array}$ \\
\hline $\begin{array}{l}\text { (Morgan et } \\
\text { al., 2020) }\end{array}$ & $\begin{array}{l}\text { PubMed (MEDLINE), } \\
\text { OVID databases } \\
\text { (PsycINFO, Embase, } \\
\text { MEDLINE, Embase } \\
\text { classic, OVID } \\
\text { MEDLINE) and Web } \\
\text { of Knowledge (all } \\
\text { databases); studies } \\
\text { published till } \\
\text { February, } 2019\end{array}$ & $\begin{array}{l}\text { 8; Meta- } \\
\text { analysis }\end{array}$ & $\begin{array}{l}\text { Sample size } \\
\text { ranged from } 10 \\
\text { to } 41\end{array}$ & $\begin{array}{l}\text { Adult participants with ASD; } \\
\text { the mean age was } 22 \text { to } 40.3 \\
\text { years; the recruitment strategy } \\
\text { and study locations were not } \\
\text { specified }\end{array}$ & $\begin{array}{l}\text { Study participants with ASD had more impaired } \\
\text { (six out of } 11 \text { ) subjective sleep parameters, } \\
\text { including lower sleep efficiency (SE) (SMD = } \\
0.87,95 \% \text { CI: }-1.14 \text { to }-0.60 \text { ), and objective } \\
\text { outcomes ( } 10 \text { out of } 17) \text {, including longer sleep } \\
\text { onset latency (PSG) (SMD }=0.86,95 \% \text { CI: } \\
0.29-1.07 \text { ) and wake after sleep onset (WASO, } \\
\text { actigraphy) (SMD }=0.57,95 \% \text { CI: } 0.28-0.87 \text { ) }\end{array}$ \\
\hline
\end{tabular}




\subsection{Sample size and characteristics of the study participants}

Most reviews evaluated primary studies with ASD populations only among which the sample size ranged from three to 210,249 (Kalyva et al., 2016; Lai et al., 2019). A few studies compared psychiatric comorbidity among ASD population with those of typically-developed control population with sample size ranging from 12 to 1,842,575 (Zheng et al., 2018). Most of the reviews reported multiple sites and strategies of recruiting study participants across primary studies. For example, Padgett and colleagues reported 19 primary studies that recruited study participants from clinical settings, registries, communities, and autism support groups (Padgett et al., 2010). Most of the reviews found participants from diverse age groups, including children, adolescents, and adults, with a majority of young participants. Five reviews evaluated psychiatric comorbidity only among the children and adolescents with ASD (Díaz-Román et al., 2018; Elrod and Hood, 2015; Menezes et al., 2018; van Steensel et al., 2011; van Steensel and Heeman, 2017). Moreover, four reviews focused only on the adult population with ASD and assessed the prevalence of psychiatric disorders among those participants (Hollocks et al., 2019; Lugo-Marín et al., 2019; Lugo Marín et al., 2018; Morgan et al., 2020).

\subsection{Prevalence of comorbid psychiatric disorders among people with ASD}

The prevalence of comorbid disorders among people with ASD varied across reviews. For example, Lugo-Marin and colleagues conducted a meta-analytic review of 47 studies and found the prevalence of at least one psychiatric disorder was 54.8\% (95\% CI: $46.6-62.7)$ among the study participants. Another systematic review by Richa and colleagues found up to $94 \%$ of the participants with ASD had psychiatric comorbidity (Richa et al., 2014). The prevalence of psychiatric disorders was different among population subgroups as well as for different methodologies and instruments used to assess those disorders. For example, Giorgi and colleagues found that participants aged above 18 years had a higher prevalence of psychiatric comorbidity compared to younger participants (De Giorgi et al., 2019). Moreover, studies with smaller sample sizes and instruments like DSM-III or later and ICD-10 had higher prevalence compared to studies with larger samples and older instruments (De Giorgi et al., 2019). The prevalence rates were different for specific psychiatric disorders, as reported in the synthesized findings of the respective reviews.

\subsubsection{Anxiety disorders}

Eight reviews reported the prevalence of anxiety disorders among people with ASD, which ranged between 1.47\% and 54\% across studies (Hollocks et al., 2019; Lai et al., 2019; LugoMarín et al., 2019; Richa et al., 2014; Skokauskas and Gallagher, 2009; van Steensel et al., 2011; van Steensel and Heeman, 2017; Zahid and Upthegrove, 2017). For example, van Steensel and colleagues evaluated anxiety disorders among 2,121 children and adolescents with ASD in a meta-analytic review, which revealed the pooled prevalence as $39.6 \%$ and $34.8 \%$ in fixed and random effects models, respectively (van Steensel et al., 2011). Another review by Hollock and colleagues reported the pooled prevalence of anxiety disorders as $42 \%$ (95\% CI: $35-50$ ) among 26,070 adults with ASD (Hollocks et al., 2019). 


\subsubsection{Depressive disorders}

The prevalence of depressive disorders among individuals with ASD was reported in six reviews, which ranged from 2.5\% to 47.1\% (Hollocks et al., 2019; Hudson et al., 2019; Lai et al., 2019; Menezes et al., 2018; Stewart et al., 2006; Wigham et al., 2017). For example, Lai and colleagues found that the prevalence of depressive disorders was 11\% (95\% CI: 9 - 13) among 162,671 samples comprising of children and adults (Lai et al., 2019). Another review by Hudson and colleagues evaluated depressive disorders in 66 studies and reported the current and lifetime prevalence as $12.3 \%$ (95\% CI: $9.7-15.5$ ) and $14.4 \%$ (95\% CI: $10.3-19.8)$, respectively (Hudson et al., 2019).

\subsubsection{Bipolar and mood disorders}

Two reviews assessed the co-occurrence of bipolar disorders in ASD (Lai et al., 2019; Vannucchi et al., 2014). Vannucchi and colleagues found the prevalence of bipolar disorders ranged from 6\% to 21.4\% across studies (Vannucchi et al., 2014), whereas Lai and colleagues reported the prevalence as 5\% (95\% CI: 3 - 6) among 153,192 people with ASD (Lai et al., 2019). Moreover, five reviews reported the prevalence of mood disorders, which ranged from 4.4\% to 37\% across ASD samples (Lugo-Marín et al., 2019; Richa et al., 2014; Skokauskas and Gallagher, 2009; Stewart et al., 2006; Zahid and Upthegrove, 2017). For example, Lugo Marín and colleagues found the prevalence of mood disorders was 18.8\% (95\% CI: 10.6 - 31.1) among 21,797 participants with ASD (Lugo-Marín et al., 2019). Another review by Stewart and colleagues found $33 \%$ of the study participants with ASD diagnoses had mood disorders (Stewart et al., 2006).

\subsubsection{Schizophrenia spectrum and other psychotic disorders}

The prevalence of schizophrenia spectrum and other psychotic disorders was reported in eight reviews, which ranged from 4\% to 67\% (De Giorgi et al., 2019; Lai et al., 2019; Lugo-Marín et al., 2019; Lugo Marín et al., 2018; Padgett et al., 2010; Skokauskas and Gallagher, 2009; Zahid and Upthegrove, 2017; Zheng et al., 2018). For example, a meta-analytic review by Zheng and colleagues found that individuals with ASD had an odds ratio of 3.55 (95\% CI: $2.08-6.05, p<$ .001) to develop schizophrenia spectrum disorders compared to the typically-developed controls (Zheng et al., 2018). Moreover, a random-effects meta-analysis by Lugo Marín found 11.8\% (95\% CI: $7.7-17.6$ ) of the 22,176 participants with ASD had schizophrenia spectrum disorders (Lugo-Marín et al., 2019).

\subsubsection{Suicidal behavior disorder}

Five reviews reported the prevalence of suicidal ideation and attempts, which ranged from 10.9\% to $66 \%$ and $1 \%$ to $35 \%$, respectively (Hannon and Taylor, 2013; Hedley and Uljarević, 2018; Richa et al., 2014; Segers and Rawana, 2014; Zahid and Upthegrove, 2017). For example, Segers and Rawana found $10.9 \%$ to $50 \%$ of the ASD populations had suicidality (Segers and Rawana, 2014), whereas Richa and colleagues found the prevalence of suicidal attempts ranged from $7.2 \%$ to $15 \%$ among participants with ASD (Richa et al., 2014). In another review, Hannon and Taylor reported a high burden of suicidal behavior cooccurring in ASD, where $31.6 \%$ and $40 \%$ 
prevalence rates of suicidal attempt were found among participants with a history of physical and sexual abuse, respectively (Hannon and Taylor, 2013).

\subsubsection{Sleep disorders}

Five reviews reported a varying prevalence of sleep disorders among individuals with ASD (Díaz-Román et al., 2018; Elrod and Hood, 2015; Lai et al., 2019; Morgan et al., 2020). For example, a meta-analytic review by Diaz-Roman and colleagues reported that individuals with ASD had impaired objective indices of sleep disorders including reduced total sleep time (-0.90, 95\% CI: -1.51 to -0.30$)$, longer sleep onset latency $(0.53,95 \%$ CI: 0.21 to 0.86$)$, higher time spent in stage 1 sleep $(0.48,95 \%$ CI: 0.06-0.90), lower time of REM sleep $(-0.88,95 \%$ CI: -1.56 to -0.21$)$, lower sleep efficiency $(-1.20,95 \% \mathrm{CI}$ : -1.98 to -0.41$)$ and higher time awake after sleep onset (0.49, 95\% CI: 0.11-0.87) (Díaz-Román et al., 2018). Another review by Lai and colleagues found that the prevalence of sleep-wake disorder was 13\% (95\% CI: 9 - 17) among 190,963 participants with ASD (Lai et al., 2019).

\subsubsection{Obsessive-compulsive and related disorders}

Three reviews assessed the prevalence of obsessive-compulsive disorders (OCD) cooccurring in ASD, which ranged from 9\% to $22 \%$ (Hollocks et al., 2019; Lai et al., 2019; van Steensel et al., 2011). For example, Hollocks and colleagues found the lifetime prevalence of OCD was $22 \%$ (95\% CI: 10 - 27) among people with ASD (Hollocks et al., 2019). In another review, van Steensel and colleagues reported $17.4 \%$ of participants with ASD had comorbid diagnoses of OCD (van Steensel et al., 2011).

\subsubsection{Disruptive, impulse-control, and conduct disorders}

Three reviews reported the prevalence of disruptive, impulse-control, and conduct disorders, which ranged from 12\% to 48\% (Lai et al., 2019; Richa et al., 2014; Zahid and Upthegrove, 2017). A meta-analytic review found the prevalence of comorbid disruptive, impulse-control, and conduct disorders were 12\% (95\% CI: $10-15)$, whereas Richa and colleagues reported the prevalence was 48\% among participants with ASD (Lai et al., 2019; Richa et al., 2014).

\subsubsection{Attention-deficit/hyperactivity disorder}

Three reviews reported the prevalence of cooccurring Attention-deficit/hyperactivity disorder (ADHD) among people with autism, which ranged from $25.7 \%$ to $65 \%$ (Hedley and Uljarević, 2018; Lai et al., 2019; Lugo-Marín et al., 2019). For example, Lugo-Marín and colleagues found the pooled prevalence of ADHD was $25.7 \%$ (95\% CI: 18.6 - 34.3) among 24,511 individuals (Lugo-Marín et al., 2019). Another review by Lai and colleagues reported the pooled prevalence as 28\% (95\% CI: 25 - 32) among 210,249 participants with ASD (Lai et al., 2019).

\subsubsection{Other comorbid psychiatric disorders}

Several comorbid psychiatric disorders are reported across reviews with varying prevalence rates. Two reviews reported the prevalence of eating disorders among individuals with ASD, which ranged from 1.4\% to 7.9\% across studies (Lugo-Marín et al., 2019; Nickel et al., 2019). For example, Nickel and colleagues found $7.9 \%$ of individuals with ASD had a current or 
previous eating disorder (ED), including anorexia nervosa (6.7\%), bulimia nervosa $(2.7 \%)$, and binge eating disorder (1.4\%) (Nickel et al., 2019). Moreover, two reviews reported the prevalence of substance use disorder in ASD, ranging from $0.7 \%$ to $36 \%$ (Arnevik and Helverschou, 2016; Lugo-Marín et al., 2019). For instance, Lugo-Marín and colleagues found the prevalence of substance use disorder was 8.3\% (95\% CI: 4.1 - 16.1) among 21,661 participants with ASD (Lugo-Marín et al., 2019). This review also reported the pooled prevalence of personality disorder as $12.6 \%$ (95\% CI: 4.8 - 29.3) among 21,715 participants. Another review by Kalyva and colleagues reported the prevalence of Tourette syndrome or tic disorders ranged between $2.6 \%$ and $36 \%$ among study participants with ASD (Kalyva et al., 2016). Furthermore, Hollocks and colleagues reported the prevalence of posttraumatic stress disorder was $1 \%(95 \% \mathrm{CI}: 0-5)$ and $5 \%(95 \% \mathrm{CI}: 1-10)$ for recent time and lifetime, respectively (Hollocks et al., 2019).

\section{Discussion}

\subsection{Overview of current evidence and recommendations for future research}

In this umbrella review, we synthesized the current evidence on the prevalence of comorbid psychiatric disorders among people with ASD. The findings of this review suggest high epidemiological burden of various psychiatric disorders including anxiety disorders, depressive disorders, bipolar and mood disorders, schizophrenia spectrum and other psychotic disorders, suicidal behavior, eating disorders, substance use disorders, obsessive-compulsive and related disorders, Attention-deficit/hyperactivity disorder, disruptive, impulse-control, and conduct disorders in ASD population. In many reviews, the psychiatric burden reported among people with ASD was enormously higher compared to the typically developed individuals (Padgett et al., 2010; van Steensel and Heeman, 2017). Such mental health disparities resulting from the coexistence of these psychiatric morbidities may critically affect the mental health status, daily life, and overall quality of living among people who are already suffering from a complex neuropsychiatric condition like ASD. However, the prevalence rates for similar psychiatric disorders have shown marked heterogeneity across reviews. Such variability in the evidence can be attributable to several factors, which should be discussed to comprehend the findings of this umbrella review adequately.

First, the operational definitions and conceptual constructs associated with many psychiatric disorders have undergone many changes in the past years, particularly with the evolution of diagnostic criteria like DSM or ICD (De Giorgi et al., 2019). In addition, the instruments used to assess a psychiatric disorder were not consistent across studies. These issues may have substantially contributed to the changing prevalence of psychiatric morbidity in ASD. Future research and evidence synthesis should evaluate the effect of those changes on the overall epidemiological burden among the ASD population.

Second, another methodological challenge identified in this review is the sampling strategies in the primary studies, as reported in the respective reviews. A major proportion of the reviews did not report the sampling techniques, which may affect the generalizability of the findings. For 
example, studies conducted in clinical settings have shown higher prevalence rates for different psychiatric disorders compared to those conducted in community settings (De Giorgi et al., 2019; Hudson et al., 2019; Zheng et al., 2018). Therefore, further evaluation would be essential to understand the true burden of psychiatric comorbidity in ASD. Population-based observational research matched with clinical profiles may provide a better understanding in this regard, which is recommended for future research in this domain.

Third, this review synthesized the prevalence of several psychiatric disorders co-occurring in ASD; however, there are many disorders that are not reported in the existing reviews. For example, several psychiatric conditions like dementia or gender dysphoria are classified under DSM-V, which can co-occur among people with ASD, as reported in primary studies (Heylens et al., 2018; Rhodus et al., 2019). The epidemiological burden of such disorders is not yet synthesized in the existing reviews. This necessitates more primary research and efforts to synthesize such findings to better inform the prevalence of diverse psychiatric conditions in the future.

Fourth, this review aimed to synthesize the prevalence of comorbid psychiatric disorders in ASD. Therefore, evaluating the moderating effects of demographic and psychosocial variables was not within the scope of this review. However, varying prevalence rates among participants from different age groups, locations, and socioeconomic conditions inform that the epigenetic and psychosocial factors associated with the epidemiological burden of psychiatric morbidity can be different across ASD samples (De Giorgi et al., 2019; Hudson et al., 2019; Segers and Rawana, 2014), which should be evaluated using different observational approaches. Such research may explain the variability in the prevalence rates and inform which subgroups within the broader ASD population are more likely to experience psychiatric morbidity.

Fifth, mental health research is largely neglected around the world, particularly in resourceconstrained contexts (Hossain and Purohit, 2019). This is also evident in the findings of this umbrella review as most of the primary studies were reported from North America, Europe, and Oceania in the included reviews, which highlights a lack of published research from Africa, Latin or Central America. Those countries have a high prevalence of ASD, but little evidence on psychiatric comorbidity is found from those countries. This gap necessitates future neuropsychiatric research to inform how cooccurring psychiatric disorders are distributed in those nations.

\subsection{Implications of psychiatric practice and health policymaking}

The findings of this review may have several implications for psychiatric practice. The cooccurrence of psychiatric disorders among individuals with ASD may create difficulties in reaching accurate diagnoses, provide specific treatments, and evaluate the prognoses. In such a scenario, mental health practitioners should evaluate the complex psychopathological dynamics that interplay between ASD and other psychiatric conditions. Moreover, a high prevalence of multiple psychiatric disorders within the same ASD population can impose a higher burden of diseases and compounding effects as psychosocial challenges, which may necessitate extensive evaluation and monitoring of mental health status among the affected individuals. Furthermore, 
many studies found a higher prevalence of psychiatric disorders among adults compared to younger participants. One implication of this phenomenon is the continued burden of psychosocial stressors across lifetime, or the expression of psychiatric diseases may increase over time, which would necessitate preventive measures for children and adolescents with ASD. Another reason for this may be the unmet need for preventive and therapeutic psychiatric services for children and adolescents, which continue to widen the gaps between mental health problems and efforts to address the same. From both of these perspectives, it is essential to strengthening psychiatric care, using both pharmacological and psychosocial approaches, at the early stages to prevent potential psychiatric morbidity among people with ASD. Furthermore, a neurodevelopmental disorder like ASD requires continued care and support from informal caregivers within community settings. Therefore, it is essential to inform the family caregivers about how different psychiatric comorbidity can affect individuals with ASD, how to prevent such problems, and how to promote positive mental health among those individuals. Also, long term prevention and community-based care approaches for mental disorders are generally nonpharmacological in nature. To address the burden of psychiatric comorbidity in ASD, it is essential to explore how different innovative approaches can be adopted in non-clinical settings to better address mental health problems with minimal involvement of mental health professionals. Two studies have shown promising impacts of such interventions in improving health outcomes among children with ASD (Benvenuto et al., 2016; Narzisi et al., 2014). Mental healthcare providers and community health workers should consider such interventions to improve mental health among younger individuals with ASD.

There are several policy implications that can be discussed in the context of the synthesized findings of this review. A high burden of coexisting psychiatric morbidity warrants a broader perspective on how the healthcare community as well as health systems can rethink the existing models of care and improve the same to address psychiatric multimorbidity in this population. For example, the provisions of care and health systems financing can be very different for neurodevelopmental disorders and other psychiatric disorders. If an individual with ASD has access to the earlier one but may not pay for the later, persistent gaps in healthcare services will exist among such individuals, which may need policy approaches to resolve such health systems challenges. Global nations should revisit their health policies and programs to ensure the institutional measures adequately meet the psychiatric demands of the ASD populations. Another policy implication is the capacities of healthcare providers, institutions, and communities to acknowledge the high burden of psychiatric comorbidity among people with ASD. It would not be feasible to protect this population from psychiatric disorders unless formal and informal healthcare providers are aware of those problems and achieve essential capacities to fulfill their responsibilities to prevent, identify, and address the psychiatric epidemic that may occur across the continuum of life among ASD populations (Pellicano et al., 2014). It is essential to empower the health workforce so that they can contribute within their professional scopes and collectively provide holistic care to individuals with ASD. In this process, strengthening primary care and community-based health services to recognize ASD and psychiatric comorbidity among the affected individuals may enhance the overall health of people with ASD (Nicolaidis et al., 2014; Saqr et al., 2018). Last but not least, policymakers across health services organizations and multilateral institutions should foster collaboration to strengthen clinical, non-clinical, and social 
care through integrated and coordinated services for people with ASD (Aylott, 2010; KałużnaCzaplińska et al., 2018). Given the high burden of ASD itself and the added challenges due to psychiatric morbidity, mobilizing collective resources may help in addressing those problems in a better way.

\subsection{Strengths and limitations of this review}

To the best of our knowledge, this is the first umbrella review that informs the prevalence of comorbid psychiatric disorders in ASD from evidence-based reviews. As we could not find another review of the reviews on this topic, it may not be appropriate to compare this review with another published article. Rather, this review critically appraised the global literature, identified systematic reviews and meta-analyses, and synthesized the findings on the prevalence of psychiatric comorbidity in ASD. Therefore, due to the methodological approaches, this review offers strong evidence on psychiatric comorbidity among people with ASD, which may facilitate future psychiatric research, practice, and policymaking around the world.

Despite those strengths, there are several limitations of this review, which should be acknowledged and addressed. First, we searched major databases and additional sources to retrieve relevant articles. However, this search was limited within the peer-reviewed journal articles. Therefore, we could not include articles that are not published within journals indexed in those databases, institutional reports, dissertations, or unpublished articles that had small effect sizes. This potential exclusion of studies which could meet our criteria highlights a publication bias within the existing body of knowledge. Secondly, our choice of databases or keywords may lead to a selection bias within the process of conducting this review, which may also affect the generalizability of this review. Third, we did not collect raw data from each primary study and conduct a patient-level quantitative analysis for each psychiatric disorder as the moderators for the same, which could have minimized the between-study variability of the synthesized findings. However, this umbrella review followed the methodological approaches as provided in the available guidelines for evidence-based reviews involving more than two reviewers as each step of the review, thus minimizing biases and methodological challenges. Future evidence syntheses adopting rigorous methods, and addressing the limitations of this review may improve the knowledge base on the prevalence of comorbid psychiatric disorders among people with ASD.

\subsection{Conclusion}

In this umbrella review, we synthesized the current evidence on the prevalence of comorbid psychiatric disorders among people with ASD from evidence-based systematic reviews and meta-analyses. The findings of this review suggest a high burden of different psychiatric disorders co-occurring among people with ASD, which is a major global mental health concern. It is essential to conduct more research to understand the burden of those disorders in low- and middle- income countries and different population groups experiencing varying levels of psychosocial distress around the world. Moreover, the limitations of the existing evidence should be addressed through multi-level research and strengthen the evidence base for better decisionmaking. Nonetheless, the findings of this review warrant multifaceted and multilevel interventions involving the mental healthcare providers, community health workers, informal 
caregivers, researchers, healthcare organizations, multilateral institutions, and health systems to ensure adequate measures for the optimal prevention, early diagnosis, and better pharmacological and psychosocial care of comorbid psychiatric disorders among people with ASD.

Declaration of interests: We declare no conflicts of interest.

Acknowledgment: None.

Role of the funding source: No funding was received at any stage of conducting this umbrella review or preparing this manuscript.

\section{References}

American Psychiatric Association, 2013. Diagnostic and Statistical Manual of Mental Disorders (DSM-5) [WWW Document]. URL https://www.psychiatry.org/psychiatrists/practice/dsm (accessed 12.5.19).

Arnevik, E.A., Helverschou, S.B., 2016. Autism Spectrum Disorder and Co-occurring Substance Use Disorder -- A Systematic Review. Subst. Abus. Res. Treat. 10, 69-75.

Aromataris, E., Fernandez, R., Godfrey, C.M., Holly, C., Khalil, H., Tungpunkom, P., 2015.

Summarizing systematic reviews: methodological development, conduct and reporting of an umbrella review approach review of reviews, systematic review, umbrella review, umbrella review methodology. Int. J. Evid. Based. Healthc. https://doi.org/10.1097/XEB.0000000000000055

Aylott, J., 2010. Improving access to health and social care for people with autism. Nurs. Stand. 24. https://doi.org/10.7748/ns2010.03.24.27.47.c7621

Bastian, H., Glasziou, P., Chalmers, I., 2010. Seventy-five trials and eleven systematic reviews a day: How will we ever keep up? PLoS Med. 7.

https://doi.org/10.1371/journal.pmed.1000326

Baxter, A.J., Brugha, T.S., Erskine, H.E., Scheurer, R.W., Vos, T., Scott, J.G., 2015. The epidemiology and global burden of autism spectrum disorders. Psychol. Med. 45, 601-613. https://doi.org/10.1017/S003329171400172X

Benvenuto, A., Battan, B., Benassi, F., Gialloreti, L.E., Curatolo, P., 2016. Effectiveness of community-based treatment on clinical outcome in children with autism spectrum disorders: An Italian prospective study. Dev. Neurorehabil. 19, 1-9. https://doi.org/10.3109/17518423.2013.864716

Brereton, A. V., Tonge, B.J., Einfeld, S.L., 2006. Psychopathology in children and adolescents with autism compared to young people with intellectual disability. J. Autism Dev. Disord. 36, 863-870. https://doi.org/10.1007/s10803-006-0125-y

De Giorgi, R., De Crescenzo, F., D’Alò, G.L., Rizzo Pesci, N., Di Franco, V., Sandini, C., 
Armando, M., 2019. Prevalence of Non-Affective Psychoses in Individuals with Autism Spectrum Disorders: A Systematic Review. J. Clin. Med. 8, 1304.

DeFilippis, M., 2018. Depression in Children and Adolescents with Autism Spectrum Disorder. Children 5, 112. https://doi.org/10.3390/children5090112

Díaz-Román, A., Zhang, J., Delorme, R., Beggiato, A., Cortese, S., 2018. Sleep in youth with autism spectrum disorders: systematic review and meta-analysis of subjective and objective studies. Evid. Based. Ment. Health 21, 146-154. https://doi.org/10.1136/ebmental-2018300037

Elrod, M.G., Hood, B.S., 2015. Sleep differences among children with autism spectrum disorders and typically developing peers: A meta-analysis. J. Dev. Behav. Pediatr. 36, 166-177. https://doi.org/10.1097/DBP.0000000000000140

Fitzpatrick, S.E., Srivorakiat, L., Wink, L.K., Pedapati, E. V., Erickson, C.A., 2016. Aggression in autism spectrum disorder: Presentation and treatment options. Neuropsychiatr. Dis. Treat. https://doi.org/10.2147/NDT.S84585

Garg, A.X., Hackam, D., Tonelli, M., 2008. Systematic review and meta-analysis: When one study is just not enough. Clin. J. Am. Soc. Nephrol. https://doi.org/10.2215/CJN.01430307

Hannon, G., Taylor, E.P., 2013. Suicidal behaviour in adolescents and young adults with ASD: Findings from a systematic review. Clin. Psychol. Rev. 33, 1197-1204. https://doi.org/10.1016/j.cpr.2013.10.003

Hedley, D., Uljarević, M., 2018. Systematic Review of Suicide in Autism Spectrum Disorder: Current Trends and Implications. Curr. Dev. Disord. Reports 5, 65-76. https://doi.org/10.1007/s40474-018-0133-6

Heylens, G., Aspeslagh, L., Dierickx, J., Baetens, K., Van Hoorde, B., De Cuypere, G., Elaut, E., 2018. The Co-occurrence of Gender Dysphoria and Autism Spectrum Disorder in Adults: An Analysis of Cross-Sectional and Clinical Chart Data. J. Autism Dev. Disord. 48, 22172223. https://doi.org/10.1007/s10803-018-3480-6

Hoefman, R., Payakachat, N., Van Exel, J., Kuhlthau, K., Kovacs, E., Pyne, J., Tilford, J.M., 2014. Caring for a child with autism spectrum disorder and parents' quality of life: Application of the CarerQol. J. Autism Dev. Disord. 44, 1933-1945. https://doi.org/10.1007/s10803-014-2066-1

Hollocks, M.J., Lerh, J.W., Magiati, I., Meiser-Stedman, R., Brugha, T.S., 2019. Anxiety and depression in adults with autism spectrum disorder: a systematic review and meta-analysis. Psychol. Med. 49, 559-572. https://doi.org/10.1017/S0033291718002283

Hossain, M.M., Purohit, N., 2019. Improving child and adolescent mental health in India: Status, services, policies, and way forward. Indian J. Psychiatry. https://doi.org/10.4103/psychiatry.IndianJPsychiatry_217_18

Hudson, C.C., Hall, L., Harkness, K.L., 2019. Prevalence of Depressive Disorders in Individuals with Autism Spectrum Disorder: a Meta-Analysis. J. Abnorm. Child Psychol. 47, 165-175.

Huerta, M., Lord, C., 2012. Diagnostic evaluation of autism spectrum disorders. Pediatr. Clin. 
North Am. https://doi.org/10.1016/j.pcl.2011.10.018

Kałużna-Czaplińska, J., Żurawicz, E., Jóźwik-Pruska, J., 2018. Focus on the Social Aspect of Autism. J. Autism Dev. Disord. https://doi.org/10.1007/s10803-017-3407-7

Kalyva, E., Kyriazi, M., Vargiami, E., Zafeiriou, D.I., 2016. A review of co-occurrence of autism spectrum disorder and tourette syndrome. Res. Autism Spectr. Disord. 24, 39-51. https://doi.org/10.1016/j.rasd.2016.01.007

Lai, M.-C., Kassee, C., Besney, R., Bonato, S., Hull, L., Mandy, W., Szatmari, P., Ameis, S.H., 2019. Prevalence of co-occurring mental health diagnoses in the autism population: A systematic review and meta-analysis. The Lancet Psychiatry. https://doi.org/10.1016/S22150366(19)30289-5

Liberati, A., Altman, D.G., Tetzlaff, J., Mulrow, C., Gotzsche, P.C., Ioannidis, J.P., Clarke, M., Devereaux, P.J., Kleijnen, J., Moher, D., 2009. The PRISMA statement for reporting systematic reviews and meta-analyses of studies that evaluate healthcare interventions: explanation and elaboration. Bmj 339, b2700. https://doi.org/10.1136/bmj.b2700

Lugo-Marín, J., Magán-Maganto, M., Rivero-Santana, A., Cuellar-Pompa, L., Alviani, M., Jenaro-Rio, C., Díez, E., Canal-Bedia, R., 2019. Prevalence of psychiatric disorders in adults with autism spectrum disorder: A systematic review and meta-analysis. Res. Autism Spectr. Disord. 59, 22-33. https://doi.org/10.1016/j.rasd.2018.12.004

Lugo Marín, J., Alviani Rodríguez-Franco, M., Mahtani Chugani, V., Magán Maganto, M., Díez Villoria, E., Canal Bedia, R., 2018. Prevalence of Schizophrenia Spectrum Disorders in Average-IQ Adults with Autism Spectrum Disorders: A Meta-analysis. J. Autism Dev. Disord. 48, 239-250. https://doi.org/10.1007/s10803-017-3328-5

Lyall, K., Croen, L., Daniels, J., Fallin, M.D., Ladd-Acosta, C., Lee, B.K., Park, B.Y., Snyder, N.W., Schendel, D., Volk, H., Windham, G.C., Newschaffer, C., 2017. The Changing Epidemiology of Autism Spectrum Disorders. Annu. Rev. Public Health 38, 81-102. https://doi.org/10.1146/annurev-publhealth-031816-044318

Masi, A., DeMayo, M.M., Glozier, N., Guastella, A.J., 2017. An Overview of Autism Spectrum Disorder, Heterogeneity and Treatment Options. Neurosci. Bull. https://doi.org/10.1007/s12264-017-0100-y

Menezes, M., Robinson, L., Sanchez, M.J., Cook, B., 2018. Depression in Youth with Autism Spectrum Disorders: a Systematic Review of Studies Published Between 2012 and 2016. Rev. J. Autism Dev. Disord. 5, 370-389. https://doi.org/10.1007/s40489-018-0146-4

Morgan, B., Nageye, F., Masi, G., Cortese, S., 2020. Sleep in adults with Autism Spectrum Disorder: a systematic review and meta-analysis of subjective and objective studies. Sleep Med. 65, 113-120. https://doi.org/10.1016/j.sleep.2019.07.019

Munn, Z., Tufanaru, C., Aromataris, E., 2014. JBI's systematic reviews: data extraction and synthesis. Am. J. Nurs. 114, 49-54. https://doi.org/10.1097/01.NAJ.0000451683.66447.89

Narzisi, A., Costanza, C., Umberto, B., Filippo, M., 2014. Non-Pharmacological Treatments in Autism Spectrum Disorders: An Overview on Early Interventions for Pre-Schoolers. Curr. Clin. Pharmacol. 9, 17-26. https://doi.org/10.2174/15748847113086660071 
Nickel, K., Maier, S., Endres, D., Joos, A., Maier, V., Tebartz van Elst, L., Zeeck, A., 2019. Systematic Review: Overlap Between Eating, Autism Spectrum, and AttentionDeficit/Hyperactivity Disorder. Front. Psychiatry 10, 708. https://doi.org/10.3389/fpsyt.2019.00708

Nicolaidis, C., Kripke, C.C., Raymaker, D., 2014. Primary care for adults on the autism spectrum. Med. Clin. North Am. https://doi.org/10.1016/j.mcna.2014.06.011

Ouzzani, M., Hammady, H., Fedorowicz, Z., Elmagarmid, A., 2016. Rayyan-a web and mobile app for systematic reviews. Syst. Rev. 5, 210. https://doi.org/10.1186/s13643-016-0384-4

Padgett, F.E., Miltsiou, E., Tiffin, P.A., 2010. The co-occurrence of nonaffective psychosis and the pervasive developmental disorders: a systematic review. J. Intellect. Dev. Disabil. 35, 187-198. https://doi.org/10.3109/13668250.2010.494596

Pellicano, E., Dinsmore, A., Charman, T., 2014. What should autism research focus upon? Community views and priorities from the United Kingdom. Autism 18, 756-770. https://doi.org/10.1177/1362361314529627

Rhodus, E.K., Barber, J., Abner, E.L., Duff, D.M.C., Bardach, S.H., Caban-Holt, A., Lightner, D., Rowles, G.D., Schmitt, F.A., Jicha, G.A., 2019. Behaviors Characteristic of Autism Spectrum Disorder in a Geriatric Cohort With Mild Cognitive Impairment or Early Dementia. Alzheimer Dis. Assoc. Disord. 1. https://doi.org/10.1097/WAD.0000000000000345

Richa, S., Fahed, M., Khoury, E., Mishara, B., 2014. Suicide in Autism Spectrum Disorders. Arch. Suicide Res. 18, 327-339. https://doi.org/10.1080/13811118.2013.824834

Romero, M., Aguilar, J.M., Del-Rey-Mejías, Á., Mayoral, F., Rapado, M., Peciña, M., Barbancho, M.Á., Ruiz-Veguilla, M., Lara, J.P., 2016. Psychiatric comorbidities in autism spectrum disorder: A comparative study between DSM-IV-TR and DSM-5 diagnosis. Int. J. Clin. Heal. Psychol. 16, 266-275. https://doi.org/10.1016/j.ijchp.2016.03.001

Saqr, Y., Braun, E., Porter, K., Barnette, D., Hanks, C., 2018. Addressing medical needs of adolescents and adults with autism spectrum disorders in a primary care setting. Autism 22, 51-61. https://doi.org/10.1177/1362361317709970

Segers, M., Rawana, J., 2014. What do we know about suicidality in autism spectrum disorders? A systematic review. Autism Res. 7, 507-521. https://doi.org/10.1002/aur.1375

Skokauskas, N., Gallagher, L., 2009. Psychosis, affective disorders and anxiety in autistic spectrum disorder: Prevalence and nosological considerations. Psychopathology 43, 8-16. https://doi.org/10.1159/000255958

Stewart, M.E., Barnard, L., Pearson, J., Hasan, R., O’Brien, G., 2006. Presentation of depression in autism and Asperger syndrome: A review. Autism 10, 103-116. https://doi.org/10.1177/1362361306062013

Tekola, B., Baheretibeb, Y., Roth, I., Tilahun, D., Fekadu, A., Hanlon, C., Hoekstra, R.A., 2016. Challenges and opportunities to improve autism services in low-income countries: lessons from a situational analysis in Ethiopia. Glob. Ment. Heal. 3. https://doi.org/10.1017/gmh.2016.17 
van Steensel, F.J.A., Bögels, S.M., Perrin, S., 2011. Anxiety disorders in children and adolescents with Autistic spectrum disorders: A meta-analysis. Clin. Child Fam. Psychol. Rev. 14, 302-317. https://doi.org/10.1007/s10567-011-0097-0

van Steensel, F.J.A., Heeman, E.J., 2017. Anxiety Levels in Children with Autism Spectrum Disorder: A Meta-Analysis. J. Child Fam. Stud. 26, 1753-1767. https://doi.org/10.1007/s10826-017-0687-7

Vannucchi, G., Masi, G., Toni, C., Dell'Osso, L., Erfurth, A., Perugi, G., 2014. Bipolar disorder in adults with Asperger's Syndrome: A systematic review. J. Affect. Disord. 168, 151-160. https://doi.org/10.1016/j.jad.2014.06.042

Wigham, S., Barton, S., Parr, J.R., Rodgers, J., 2017. A Systematic Review of the Rates of Depression in Children and Adults With High-Functioning Autism Spectrum Disorder. J. Ment. Health Res. Intellect. Disabil. 10, 267-287. https://doi.org/10.1080/19315864.2017.1299267

World Health Organization (WHO), 2016. International Classification of Diseases (ICD-10) Version:2016 [WWW Document]. URL https://icd.who.int/browse10/2016/en (accessed 12.5.19).

Yerys, B.E., Wallace, G.L., Jankowski, K.F., Bollich, A., Kenworthy, L., 2011. Impaired Consonant Trigrams Test (CTT) performance relates to everyday working memory difficulties in children with Autism Spectrum Disorders. Child Neuropsychol. 17, 391-399. https://doi.org/10.1080/09297049.2010.547462

Zahid, S., Upthegrove, R., 2017. Suicidality in autistic spectrum disorders: A systematic review. Cris. J. Cris. Interv. Suicide Prev. 38, 237-246. https://doi.org/10.1027/0227-5910/a000458

Zheng, Z., Zheng, P., Zou, X., 2018. Association between schizophrenia and autism spectrum disorder: A systematic review and meta-analysis. Autism Res. https://doi.org/10.1002/aur.1977 
Supplemental file 1: Critical appraisal of the systematic reviews and meta-analyses

\begin{tabular}{|c|c|c|c|c|c|c|c|c|c|c|c|}
\hline Sources & $\begin{array}{l}\text { Is the } \\
\text { review } \\
\text { question } \\
\text { clearly } \\
\text { and } \\
\text { explicitly } \\
\text { stated? }\end{array}$ & $\begin{array}{l}\text { Were the } \\
\text { inclusion } \\
\text { criteria } \\
\text { appropriate } \\
\text { for the } \\
\text { review } \\
\text { question? }\end{array}$ & $\begin{array}{l}\text { Was the } \\
\text { search } \\
\text { strategy } \\
\text { appropriate } \\
?\end{array}$ & $\begin{array}{l}\text { Were the } \\
\text { sources } \\
\text { and } \\
\text { resources } \\
\text { used to } \\
\text { search for } \\
\text { studies } \\
\text { adequate? }\end{array}$ & $\begin{array}{l}\text { Were the } \\
\text { criteria for } \\
\text { appraising } \\
\text { studies } \\
\text { appropriate? }\end{array}$ & $\begin{array}{l}\text { Was critical } \\
\text { appraisal } \\
\text { conducted } \\
\text { by two or } \\
\text { more } \\
\text { reviewers } \\
\text { independent } \\
\text { ly? }\end{array}$ & $\begin{array}{l}\text { Were the } \\
\text { methods used } \\
\text { to combine } \\
\text { studies } \\
\text { appropriate? }\end{array}$ & $\begin{array}{l}\text { Was the } \\
\text { likelihood } \\
\text { of } \\
\text { publicatio } \\
\text { n bias } \\
\text { assessed? }\end{array}$ & $\begin{array}{l}\text { Were } \\
\text { recommend } \\
\text { ations for } \\
\text { policy } \\
\text { and/or } \\
\text { practice } \\
\text { supported } \\
\text { by the } \\
\text { reported } \\
\text { data? }\end{array}$ & $\begin{array}{l}\text { Were the } \\
\text { specific } \\
\text { directives } \\
\text { for new } \\
\text { research } \\
\text { appropriat } \\
\text { e? }\end{array}$ & $\begin{array}{l}\text { Overall } \\
\text { score and } \\
\text { quality } \\
\text { rating }\end{array}$ \\
\hline $\begin{array}{l}\text { (Stewart et } \\
\text { al., 2006) }\end{array}$ & Yes & Yes & Yes & Yes & No & No & Yes & No & Yes & Yes & $\begin{array}{l}7 \\
\text { (Medium) }\end{array}$ \\
\hline $\begin{array}{l}\text { (Skokauskas } \\
\text { and } \\
\text { Gallagher, } \\
\text { 2009) }\end{array}$ & Yes & Yes & Yes & Yes & No & No & Yes & No & Yes & Yes & $\begin{array}{l}7 \\
\text { (Medium) }\end{array}$ \\
\hline $\begin{array}{l}\text { (Padgett et } \\
\text { al., 2010) }\end{array}$ & Yes & Yes & Yes & Yes & No & No & Yes & No & Yes & Yes & $\begin{array}{l}7 \\
\text { (Medium) }\end{array}$ \\
\hline $\begin{array}{l}\text { (van Steensel } \\
\text { et al., 2011) }\end{array}$ & Yes & Yes & Yes & Yes & No & Yes & Yes & Yes & Yes & Yes & 9 (High) \\
\hline $\begin{array}{l}\text { (Hannon and } \\
\text { Taylor, 2013) }\end{array}$ & Yes & Yes & Yes & Yes & No & No & Yes & No & Yes & Yes & $\begin{array}{l}7 \\
\text { (Medium) }\end{array}$ \\
\hline $\begin{array}{l}\text { (Segers and } \\
\text { Rawana, } \\
\text { 2014) } \\
\end{array}$ & Yes & Yes & Yes & Yes & No & No & Yes & No & Yes & Yes & $\begin{array}{l}7 \\
\text { (Medium) }\end{array}$ \\
\hline $\begin{array}{l}\text { (Richa et al., } \\
\text { 2014) }\end{array}$ & Yes & Yes & Yes & Yes & No & No & Yes & No & Yes & Yes & $\begin{array}{l}7 \\
\text { (Medium) }\end{array}$ \\
\hline $\begin{array}{l}\text { (Vannucchi et } \\
\text { al., 2014) }\end{array}$ & Yes & Yes & Yes & $\mathrm{CD}$ & No & $\mathrm{CD}$ & No & No & Yes & Yes & $\begin{array}{l}5 \\
\text { (Medium) } \\
\end{array}$ \\
\hline $\begin{array}{l}\text { Elrod and } \\
\text { Hood, 2015) }\end{array}$ & Yes & Yes & Yes & Yes & Yes & Yes & Yes & Yes & $\mathrm{CD}$ & Yes & 9 (High) \\
\hline $\begin{array}{l}\text { (Kalyva et al., } \\
\text { 2016) }\end{array}$ & Yes & Yes & Yes & Yes & No & No & Yes & No & No & Yes & $\begin{array}{l}6 \\
\text { (Medium) }\end{array}$ \\
\hline $\begin{array}{l}\text { (Arnevik and } \\
\text { Helverschou, } \\
\text { 2016) }\end{array}$ & Yes & Yes & Yes & Yes & No & $\mathrm{CD}$ & Yes & No & Yes & Yes & $\begin{array}{l}7 \\
\text { (Medium) }\end{array}$ \\
\hline $\begin{array}{l}\text { (van Steensel } \\
\text { and Heeman, } \\
\text { 2017) }\end{array}$ & Yes & Yes & Yes & Yes & Yes & $\mathrm{CD}$ & Yes & Yes & Yes & Yes & 9 (High) \\
\hline $\begin{array}{l}\text { (Wigham et } \\
\text { al., 2017) }\end{array}$ & Yes & Yes & Yes & Yes & Yes & $\mathrm{CD}$ & Yes & No & Yes & Yes & 8 (High) \\
\hline
\end{tabular}




\begin{tabular}{|c|c|c|c|c|c|c|c|c|c|c|c|}
\hline $\begin{array}{l}\text { (Zahid and } \\
\text { Upthegrove, } \\
\text { 2017) }\end{array}$ & Yes & Yes & Yes & Yes & $\mathrm{CD}$ & $\mathrm{CD}$ & Yes & No & Yes & Yes & $\begin{array}{l}7 \\
\text { (Medium) }\end{array}$ \\
\hline $\begin{array}{l}\text { (Hollocks et } \\
\text { al., 2019) }\end{array}$ & Yes & Yes & Yes & Yes & Yes & No & Yes & No & Yes & Yes & 8 (High) \\
\hline $\begin{array}{l}\text { (Hudson et } \\
\text { al., 2019) }\end{array}$ & Yes & Yes & Yes & Yes & Yes & Yes & Yes & Yes & Yes & Yes & 10 (High) \\
\hline $\begin{array}{l}\text { (Lugo Marín } \\
\text { et al., 2018) }\end{array}$ & Yes & Yes & Yes & Yes & Yes & Yes & Yes & Yes & Yes & Yes & 10 (High) \\
\hline $\begin{array}{l}\text { (Menezes et } \\
\text { al., 2018) }\end{array}$ & Yes & Yes & Yes & Yes & No & Yes & Yes & No & Yes & Yes & 8 (High) \\
\hline $\begin{array}{l}\text { (Díaz-Román } \\
\text { et al., 2018) }\end{array}$ & Yes & Yes & Yes & Yes & Yes & Yes & Yes & Yes & Yes & Yes & 10 (High) \\
\hline $\begin{array}{l}\text { (Hedley and } \\
\text { Uljarević, } \\
\text { 2018) }\end{array}$ & Yes & Yes & Yes & Yes & No & No & Yes & No & Yes & Yes & $\begin{array}{l}7 \\
\text { (Medium) }\end{array}$ \\
\hline $\begin{array}{l}\text { (Zheng et al., } \\
\text { 2018) }\end{array}$ & Yes & Yes & Yes & Yes & Yes & $\mathrm{CD}$ & Yes & Yes & $\mathrm{CD}$ & Yes & 8 (High) \\
\hline $\begin{array}{l}\text { (De Giorgi et } \\
\text { al., 2019) }\end{array}$ & Yes & Yes & Yes & Yes & Yes & Yes & Yes & No & Yes & Yes & 9 (High) \\
\hline $\begin{array}{l}\text { (Lai et al., } \\
\text { 2019) }\end{array}$ & Yes & Yes & Yes & Yes & Yes & Yes & Yes & $\mathrm{CD}$ & Yes & Yes & 9 (High) \\
\hline $\begin{array}{l}\text { (Lugo-Marín } \\
\text { et al., 2019) }\end{array}$ & Yes & Yes & Yes & Yes & Yes & Yes & Yes & Yes & Yes & Yes & 10 (High) \\
\hline $\begin{array}{l}\text { (Nickel et al., } \\
2019)\end{array}$ & Yes & Yes & Yes & Yes & No & No & Yes & No & Yes & Yes & $\begin{array}{l}7 \\
\text { (Medium) }\end{array}$ \\
\hline $\begin{array}{l}\text { (Morgan et } \\
\text { al., 2020) }\end{array}$ & Yes & Yes & Yes & Yes & Yes & Yes & Yes & No & Yes & Yes & 9 (High) \\
\hline
\end{tabular}

(Abbreviations: $\mathrm{CD}=$ could not determine) 